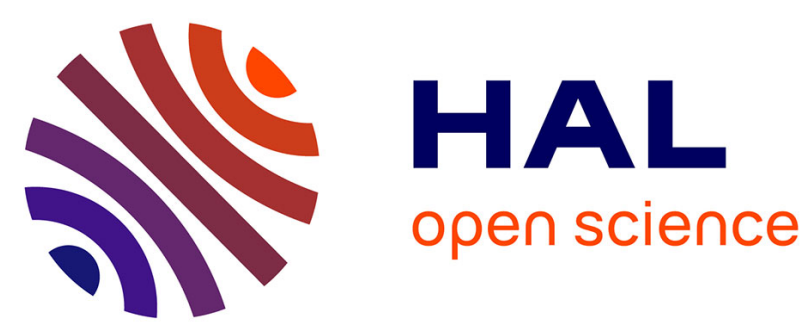

\title{
Determination of the collision cross sections of cardiolipins and phospholipids from Pseudomonas aeruginosa by traveling wave ion mobility spectrometry-mass spectrometry using a novel correction strategy
}

Estelle Deschamps, Isabelle Schmitz-Afonso, Annick Schaumann, Emmanuelle Dé, Corinne Loutelier-Bourhis, Stephane Alexandre, Carlos Afonso

\section{- To cite this version:}

Estelle Deschamps, Isabelle Schmitz-Afonso, Annick Schaumann, Emmanuelle Dé, Corinne LoutelierBourhis, et al.. Determination of the collision cross sections of cardiolipins and phospholipids from Pseudomonas aeruginosa by traveling wave ion mobility spectrometry-mass spectrometry using a novel correction strategy. Analytical and Bioanalytical Chemistry, 2019, 411 (30), pp.8123-8131. 10.1007/s00216-019-02194-2 . hal-02380002

\section{HAL Id: hal-02380002 https://hal.science/hal-02380002}

Submitted on 8 Dec 2020

HAL is a multi-disciplinary open access archive for the deposit and dissemination of scientific research documents, whether they are published or not. The documents may come from teaching and research institutions in France or abroad, or from public or private research centers.
L'archive ouverte pluridisciplinaire $\mathbf{H A L}$, est destinée au dépôt et à la diffusion de documents scientifiques de niveau recherche, publiés ou non, émanant des établissements d'enseignement et de recherche français ou étrangers, des laboratoires publics ou privés. 
1 Determination of the collision cross sections of cardiolipins and phospholipids from

2 Pseudomonas aeruginosa by traveling wave ion mobility spectrometry-mass spectrometry

3 using a novel correction strategy

4

5 Estelle Deschamps ${ }^{1,2}$, Isabelle Schmitz-Afonso ${ }^{1}$, Annick Schaumann ${ }^{2}$, Emmanuelle Dé2,

6 Corinne Loutelier-Bourhis ${ }^{1}$, Stéphane Alexandre ${ }^{2}$, Carlos Afonso ${ }^{1}$

7

81 Normandie Univ, COBRA, UMR 6014 and FR 3038, Université de Rouen, INSA de

9 Rouen, CNRS, IRCOF, 1 rue Tesnière, 76821 Mont-Saint-Aignan Cedex, France

102 Normandie Univ, PBS, UMR 6270 and FR 3038, Université de Rouen, INSA de Rouen,

11 CNRS, CURIB, 25 Rue Lucien Tesnière, 76821 Mont-Saint-Aignan Cedex, France

12

13 Corresponding authors :

$14 * \quad$ Estelle Deschamps estelle.deschamps@etu.univ-rouen.fr

$15 * \quad$ Corinne Loutelier-Bourhis corinne.loutelier@univ-rouen.fr

16

17 Keywords: Ion mobility spectrometry, Mass spectrometry, Pseudomonas aeruginosa, 18 Cardiolipins, Phospholipids, CCS calibration

19

20 Received: 22 July 2019 / Revised: 16 September 2019 / Accepted: 7 October 2019 /

21 Published online: 27 November 2019 
Collision Cross Section (CCS) values are descriptors of the 3D structure of ions which can be determined by ion mobility spectrometry (IMS). Currently, most lipidomic studies involving CCS values determination concerns eukaryote samples (e.g. human, bovine) and to a lower extent prokaryote samples (e.g. bacteria). Here, we report CCS values obtained from Traveling Wave Ion Mobility spectrometry $\left({ }^{\mathrm{TW}} \mathrm{CCS}_{\mathrm{N} 2}\right)$ measurements from the bacterial membrane of Pseudomonas aeruginosa - a bacterium ranked as priority 1 for the R\&D of new antibiotics by the World Health Organization. In order to cover the lack of reference compounds which could cover the $m / z$ and CCS range of the membrane lipids of $P$. aeruginosa, three calibrants (polyalanine, dextran and phospholipids) were used for the ${ }^{\mathrm{TW}} \mathrm{CCS}_{\mathrm{N} 2}$ calibration. A shift from the published lipids CCS values was systematically observed ( $\triangle \mathrm{CCS} \%$ up to $9 \%$ ), thus we proposed a CCS correction strategy. This correction strategy allowed to reduce the shift $(\Delta \mathrm{CCS} \%)$ between our measurements and published values to less than $2 \%$. This correction was then applied to determine the CCS values of Pseudomonas aeruginosa lipids which have not been published yet. As a result, $32{ }^{\mathrm{TW}} \mathrm{CCS}_{\mathrm{N} 2}$ values for $[\mathrm{M}+\mathrm{H}]$ ${ }^{+}$ions and $24{ }^{\mathrm{TW}} \mathrm{CCS}_{\mathrm{N} 2}$ values for $[\mathrm{M}-\mathrm{H}]^{-}$ions were obtained for four classes of phospholipids (phosphatidylethanolamines (PE), phosphatidylcholines (PC), phosphatidylglycerols (PG) and diphosphatidylglycerols - known as cardiolipins (CL)).
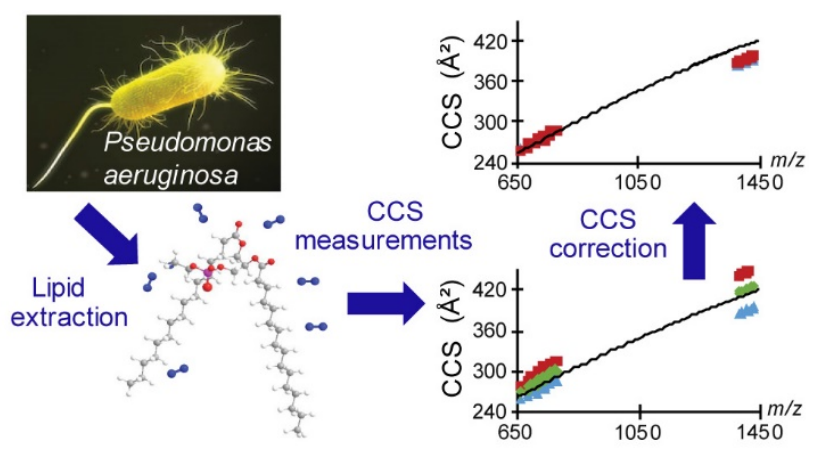


\section{1}

\section{INTRODUCTION}

Pseudomonas aeruginosa is a bacterium known to have intrinsic resistances to antibiotics and easily acquire genes encoding resistance to new drugs [1]. This bacterium is responsible of $18 \%$ of the bacteria-induced nosocomial pneumonia [2] which, combined with its virulence, dramatically increases the death rate of immunocompromised patients. As a result, $P$. aeruginosa is one of the deadliest bacteria in hospitals, thus ranked by the World Health Organization (WHO) as priority number one for the R\&D of new antibiotics [3].

Due to the numerous resistance mechanisms of $P$. aeruginosa against antibiotics targeting proteins or enzymes [4], new antibiotic strategies are required. One of the current new drug strategies involves membrane cell destabilization or destruction leading to the bacteria lysis [5]. Thus, it is necessary to know the composition and 3D structure of the membrane cell lipids to develop such antibiotics. However, while the proteome of $P$. aeruginosa has been extensively studied [6-8], only few data have been reported on the mem- brane cell lipidome of $P$. aeruginosa $[9,10]$.

Here, we focused on the membrane lipids of $P$. aeruginosa and especially on the identification of the different compounds by ion mobility spectrometry coupled to mass spectrometry (IMS-MS). IMS is a post-ionization separation technique in which analyte ions travel through an inert gas (generally $\mathrm{N}_{2}$ or $\mathrm{He}$ ) in a cell under the influence of an electric field. For equal charge state, the most compact ions will have the smallest drift times since they are less slowed down by the buffer gas than the largest ions. Consequently, the IMS separation depends on charge, size and shape $[11,12]$. Moreover, drift time $\left(t_{D}\right)$ can be converted to the experimental collision cross section (CCS) of the ion within the buffer gas. CCS values are closely related to the 3D structure of each ion. These experimental CCS can be compared with calculated CCS obtained from theoretical structures using computational methods (i.e. trajectory meth- od (TM), projection approximation (PA) and exact hard sphere scattering (EHSS) methods [13]) or CCS predicted by using a machine learning approach [14] as CCS are predictable values [15]. 
For CCS determination, in most cases, and in particular for non-uniform field instruments such as traveling wave ion mobility spectrometry (TWIMS), the use of calibration is required with compounds of known CCS [16]. As an example, polyalanine, one of the most common calibrant for TWIMS, has been used for lipid CCS determination [1719]. However, caution must be taken when choosing calibrants since shifts with the literature can be observed when using calibrants not chemically close to the sample [13]. Indeed, Hines et al. [20] confirmed that using calibrants structurally close to targets reduced the error in calibrated CCS values obtained with TWIMS. Thus, PCS are recommended for phospholipid calibration in positive mode and PEs for phospholipid calibration in negative mode [21]. Using definite calibrants, CCS values are extremely repeatable (RSD < 0.5\%) [22], reproducible in intra-laboratory studies (RSD < 2\%) [23] and reproducible in inter-laboratory studies (RSD $<5 \%$ using different ion mobility techniques, RSD $<2 \%$ using drift-tube) [19]. Consequently, CCS values can be used as an additional descriptor, together with $\mathrm{m} / \mathrm{z}$ and retention time, to increase the confidence in automatic identification [19, 24]. For such reasons, the number of biological sample studies using IMS as a separation and characterization tool has been constantly increasing over the last decade [15, 17-20, 24-30].

Herein, we report the identification of the cell membrane phospholipids of $P$. aeruginosa strain PAK (PAK) and the experimental CCS values of their positive and negative ions. The data were acquired on a TWIMS, with nitrogen as drift gas, yielding ${ }^{\mathrm{TW}} \mathrm{CCS}_{\mathrm{N} 2}$ values based on conventional notations [23]. To ensure our ${ }^{{ }^{T W}} \mathrm{CCS}_{\mathrm{N} 2}$ measurements, we used three approaches with different calibrating substances: (i) polyalanine [19] and (ii) lipid calibrants [20] which have been previously used for phospholipids, (iii) dextran which is a calibrant that can cover the required $\mathrm{m} / \mathrm{z}$ and CCS ranges of PAK lipids, from the short fatty acyl chain phospholipids to the cardiolipins. We show here that the use of polyalanine or dextran requires a post-calibration ${ }^{\mathrm{TW}} \mathrm{CCS}_{\mathrm{N} 2}$ correction using commercial phospholipid standards. This correction strategy was validated by comparing our corrected ${ }^{{ }^{T} \mathrm{~W}} \mathrm{CCS}_{\mathrm{N} 2}$ values with ${ }^{\mathrm{DT}} \mathrm{CCS} \mathrm{N}_{\mathrm{N} 2}$ values of the literature. Then, the correction was applied to all the ${ }^{\mathrm{TW}} \mathrm{CCS}_{\mathrm{N} 2}$ values of $P$. aeruginosa lipids. It is the first time to our knowledge that experimental ${ }^{\mathrm{TW}} \mathrm{CCS}_{\mathrm{N} 2}$ values of both protonated and deprotonated ions of diphosphatidylglycerols-commonly called cardiolipins (CL)-are reported. 
102

103

104

105

106

107

108

109

110

111

112

113

114

115

116

117

118

119

120

121

122

123

124

125

126

127

128

129

130

\section{MATERIAL AND METHODS}

\section{Chemicals and reagents}

Milli-Q grade water was obtained from an $18 \mathrm{M} \Omega$ Milli-Q (EMD Millipore Corporation, Molsheim, France). Methanol, chloroform, acetonitrile and isopropanol were purchased from Fischer Scientific (UK), ammonium formate from Sigma-Aldrich (Saint Quentin Fallavier, France) and formic acid from Merck (Germany). Except for chloroform which was HPLC grade, all solvents and buffers used were LC-MS grade. Polyalanine and dextran, used as IMS calibration substances, were purchased from Sigma-Aldrich (Saint Quentin Fallavier, France). Phospholipid standards for the IMS calibration were purchased from Avanti Polar Lipids (AL, USA): PE 6:0/6:0, PE 10:0/10:0, PE 15:0/15:0, PE 17:0/17:0, PC 17:0/17:0, PC 20:0/20:0, PC 24:0/24:0. Leucine enkephalin was purchased from SigmaAldrich (Saint Quentin Fallavier, France).

\section{Biological sample preparation}

A P. aeruginosa strain PAK (PAK) was pre-cultured in a $50-\mathrm{mL}$ centrifugal tube containing $20 \mu \mathrm{L}$ of bacterial stock solution (Muller-Hinton Broth (MHB)/glycerol, 70/30) and $20 \mathrm{~mL}$ of MHB. The flask was incubated overnight at $37^{\circ} \mathrm{C}$ on a rotary shaker $(140 \mathrm{rpm})$. After incubation, the pre-culture was used to inoculate $330 \mathrm{~mL}$ of $\mathrm{MHB}$ at a final concentration of $10^{4}$ colony-forming units (CFU)/mL in a $1 \mathrm{~L}$ Erlenmeyer flask. The culture was incubated on a rotary shaker $(140 \mathrm{rpm})$ at $37^{\circ} \mathrm{C}$ for $7 \mathrm{~h}$. Then, the culture was centrifuged $\left(2600 \times \mathrm{g}, 10 \mathrm{~min}, 20^{\circ} \mathrm{C}\right)$. The obtained pellet was washed in $10 \mathrm{~mL}$ of $100 \mathrm{mM}$ Tris pH 8.0. Ten milliliters of phosphate-buffered saline (PBS) and $3 \mathrm{mg}$ of alginate lyase were added at room temperature during $1 \mathrm{~h}$ for the lysis of alginates, produced by $P$. aeruginosa PAK strain, which can be deleterious for mass spectrometric analysis. A pellet was obtained by centrifugation $\left(5000 \times \mathrm{g}, 10 \mathrm{~min}, 20^{\circ} \mathrm{C}\right.$ ) and washed in $100 \mathrm{mM}$ Tris $\mathrm{pH} 8.0$. The pellet was resuspended in $6 \mathrm{~mL}$ of $100 \mathrm{mM}$ Tris $\mathrm{pH} 8.0$ and was subjected to sonication (cycles of $30 \mathrm{~s}$ on/10 s off for $2 \mathrm{~min}$ ). The suspension was then centrifuged $\left(5200 \times \mathrm{g}, 20 \mathrm{~min}, 20^{\circ} \mathrm{C}\right.$ ). The supernatant, containing the inner and outer membranes, was ultra-centrifuged $(70,000 \times g, 1$ $\mathrm{h}, 4^{\circ} \mathrm{C}$ ), then the resulting pellet was stocked at $-20^{\circ} \mathrm{C}$. 
Finally, the lipid extraction was carried out according to an adapted Bligh and Dyer protocol [31]. After waiting for the pellet to warm up to room temperature, $500 \mu \mathrm{L}$ of Milli-Q water was added to dissolve the pellet and then vortex mixed for $5 \mathrm{~min} .1 .2 \mathrm{~mL}$ of methanol was added and then vortex mixed for $15 \mathrm{~min}$. To degrade and eliminate proteolipids, the mixture was centrifuged $\left(4000 \times g, 10 \mathrm{~min}, 22^{\circ} \mathrm{C}\right)$, then the liquid phase was recovered. After adding $0.6 \mathrm{~mL}$ of chloroform, the solution was vortex mixed for $15 \mathrm{~min}$ and sonicated for 15 $\min .0 .6 \mathrm{~mL}$ of chloroform was added and then vortex mixed for another $15 \mathrm{~min} .0 .62 \mathrm{~mL}$ of a $1 \mathrm{M}$ ammonium acetate was added and vortex mixed for $15 \mathrm{~min}$. Finally, the mixture was left to rest for $30 \mathrm{~min}$ in order to allow the three phase separation (aqueous phase, protein interphase and organic phase). One milliliter of the organic phase was recovered and 0.94 $\mathrm{mL}$ of chloroform was added to the aqueous phase for a second liquid-liquid extraction. After stirring for $15 \mathrm{~min}$, the mixture was left to rest again for $30 \mathrm{~min}$. The aqueous phase was removed and organic phases were mixed and evaporated under argon. The organic phase was separated in aliquots and evaporated under argon. Lipid extracts were conserved under argon at $-20^{\circ} \mathrm{C}$. To ascertain the quantity of lipids obtained, one aliquot of the lipid extract was diluted in a chloroform: methanol $(4 / 1, v / v)$ solution. Then, the lipid extract concentration was checked by measuring the surface pressure of Langmuir monolayers.

\section{Sample and calibrant mix solution preparation}

The lipids extracted from the membrane of PAK were reconstituted in chloroform/methanol $(2 / 1, \mathrm{v} / \mathrm{v})$ to obtain a concentration of $1 \mu \mathrm{g} / \mu \mathrm{L}$ which was estimated as previously mentioned. Five microliters of this solution was then diluted in $20 \mu \mathrm{L}$ of isopropanol/acetonitrile/water $(4 / 3 / 1, \mathrm{v} / \mathrm{v})$ for analysis. The dextran calibrant solution was prepared from a stock solution ( $1 \mathrm{mg} / \mathrm{mL}$ in water) diluted to $10^{-5} \mathrm{~mol} / \mathrm{L}$ in water/ acetonitrile $(1 / 1, v / v)$. The polyalanine calibrant solution was prepared from a stock solution $\left(1 \mathrm{mg} / \mathrm{mL}\right.$ in water/acetonitrile $(1 / 1, \mathrm{v} / \mathrm{v})$ ) diluted to $10^{-5} \mathrm{~mol} / \mathrm{L}$ in water/acetonitrile/acetic acid (49.5/49.5/1, v/v). Commercial PEs and PCs used as IMS standards were individually dissolved at $10^{-4} \mathrm{~mol} / \mathrm{L}$ in chloroform/methanol $(2 / 1, \mathrm{v} / \mathrm{v})$, then mixed and diluted in isopropanol/acetonitrile/water $(4 / 3 / 1, \mathrm{v} / \mathrm{v})$ to obtain a lipid calibrant solution at $10^{-5} \mathrm{~mol} / \mathrm{L}$. 
160

161

162

163

164

165

\section{Instrumentation}

The LC-IMS-MS experiments were performed using an UHPLC system (Dionex Ultimate 3000 RSLC, Thermo Scientific, San Jose, CA, USA) coupled to an IMS Q-TOF mass spectrometer (SYNAPT G2 HDMS, Waters MS Technologies, Manchester, UK) equipped with an electrospray interface, a traveling wave ion mobility (TWIMS) cell. Data treatment was performed with MassLynx 4.1, DriftScope 2.8 and UNIFI 1.8.2.169 software (Waters, Manchester, UK).

The column used was a $1.0 \times 100 \mathrm{~mm}$, Acquity UPLC CSH C18 $1.7 \mu \mathrm{m}$ column (Waters, Manchester, UK) equipped with a $0.2 \mu \mathrm{m}$ prefilter. The sample tray and column oven temperatures were set at $4{ }^{\circ} \mathrm{C}$ and $50{ }^{\circ} \mathrm{C}$, respectively. The injection volume was set at $1 \mu \mathrm{L}$. A flow rate of $100 \mu \mathrm{L} /$ min was used. Mobile phase A consisted of acetonitrile/ aqueous 10 $\mathrm{mM}$ ammonium formate $(60 / 40)+0.1 \%$ formic acid and mobile phase $\mathrm{B}$ of isopropanol/acetonitrile/aqueous $10 \mathrm{mM}$ ammonium formate (88/8/4) + $0.1 \%$ formic acid. The gradient elution was the following: 0-3 min, 6-62\% B; 3-8 min, 62-70\% B; 8-13 min, $70 \% \mathrm{~B} ; 13-15 \mathrm{~min}, 70-89 \% \mathrm{~B} ; 15-20 \mathrm{~min}, 89 \% \mathrm{~B} ; 20-22 \mathrm{~min}, 89-100 \% \mathrm{~B} ; 22-26 \mathrm{~min}$, $100 \% \mathrm{~B} ; 26-27 \mathrm{~min}, 100-6 \% \mathrm{~B} ; 27-30 \mathrm{~min}, 6 \% \mathrm{~B}$.

LC-IMS-MS data were acquired in triplicate in positive and negative ion modes. The source parameters were in positive mode: capillary, extraction cone and cone voltages set at $3 \mathrm{kV}, 6 \mathrm{~V}$ and $50 \mathrm{~V}$, respectively; the cone gas and desolvation gas flows were $40 \mathrm{~L} / \mathrm{h}$ and 600 $\mathrm{L} / \mathrm{h}$, respectively; and the desolvation temperature was $400{ }^{\circ} \mathrm{C}$. For negative ion mode, the capillary, extraction cone and cone voltage were $-2.4 \mathrm{kV}, 5 \mathrm{~V}$ and $45 \mathrm{~V}$, respectively; the cone gas and desolvation gas flows were $60 \mathrm{~L} / \mathrm{h}$ and $900 \mathrm{~L} / \mathrm{h}$, respectively; and the desolvation temperature was $500^{\circ} \mathrm{C}$.

The IMS parameters were helium cell flow $180 \mathrm{~mL} / \mathrm{min}$, traveling wave height $40 \mathrm{~V}$, IMS cell nitrogen flow $70 \mathrm{~mL} / \mathrm{min}$ (3.01 mbar) and traveling wave velocity $600 \mathrm{~m} / \mathrm{s}$.

Mass spectra were recorded over a $m / z$ 50-2000 range in resolution mode (resolution 20000 FWHM). External $m / z$ calibration was performed with a sodium formate solution. 
187

Lockmass correction was performed by infusing leucine enkephalin ( $2 \mathrm{ng} / \mu \mathrm{L}, 3 \mu \mathrm{L} / \mathrm{min}$ ) via the LockSpray $^{\mathrm{TM}}$ interface (reference scan frequency, lock spray capillary and cone voltage of $10 \mathrm{~s}$, $3.5 \mathrm{kV}$ and $40 \mathrm{~V}$, respectively, in positive mode and $10 \mathrm{~s}, 2.5 \mathrm{kVand} 30 \mathrm{~V}$, respectively, in negative mode).

MS/MS experiments were performed in both positive and negative ionization mode. Precursor ions were selected in the quadrupole, at a resolution of $1 \mathrm{~m} / \mathrm{z}$ unit, using retention time windows in the acquisition method. Several acquisitions were performed to obtain the MS/MS spectra for all co-eluting lipids. The collisional activation was performed in the trap cell using argon as target gas $\left(6.10^{-3} \mathrm{mbar}\right)$ and a collision energy of $35 \mathrm{eV}$. MS/MS spectra were processed using MassLynx 4.1 (Waters).

For calibrants, raw data were first opened with DriftScope 2.8 (Waters) in order to only select the singly charged ions on the 2D map (drift times plotted against $\mathrm{m} / \mathrm{z}$ ). Ion mobility spectra were then exported and processed with MassLynx 4.1 (Waters). For PAK samples, raw data were processed with UNIFI 1.8.2.169 (Waters). PAK lipids were first manually identified in order to create a home-made library from retention time $\left(t_{R}\right)$ and $\mathrm{m} / \mathrm{z}$, for each of the lipids described in this publication. This library was then used to automatically obtain the lipids $t_{\mathrm{D}}$.

\section{Collision cross section measurements}

Due to the use of an inhomogeneous electric field in the TWIMS cell, an external CCS calibration is required. For this purpose, we used singly charged ions of three published calibrants: dextran oligomers [32,33], polyalanine oligomers [34] and phospholipids (PEs and PCs) [20]. Thus, these calibrant solutions were individually infused for 2 min in positive and negative modes. Ion mobility spectra were fitted with a Gauss function [35] using OriginPro 2016 9.3.226 (OriginLab Corporation) to obtain the drift time of each calibrant ion. Using charge- and mass-independent ${ }^{\mathrm{DT}} \mathrm{CCS}_{\mathrm{N} 2}$ values $\left(\mathrm{CCS}^{\prime}\right)$ and drift times $\left(t_{\mathrm{D}}\right)$, calibration curves In $C^{\prime} S^{\prime}=f\left(\ln t_{D}\right)$, for singly charged positive and negative ions, were obtained in nitrogen according to the procedure of Smith [16]. LC-IMS-MS data of the PAK sample were 
215 processed with the UNIFI software (Waters) in order to automatically obtain drift time 216 values.

217 Drift time values were collected for retention time variation lower than 0.3 min, mass error lower than $5 \mathrm{ppm}$ and relative intensity higher than $0.1 \%$.

219 Then, ${ }^{\mathrm{TW}} \mathrm{CCS}_{\mathrm{N} 2}$ were determined using the calibration curve established previously. Finally, the ${ }^{\mathrm{TW}} \mathrm{CCS}_{\mathrm{N} 2}$ values were corrected using the CCS correction strategy that will be developed in the

221

222

\section{RESULTS AND DISCUSSION}

\section{Lipid profiling}

The LC-IMS-MS analysis of PAK membrane extract is reported in Fig. 1. The LC dimension allows the separation of the different classes of lipids, i.e. phosphatidylcholines (PC), phosphatidylethanolamines (PE), phosphatidylglycerols (PG) and cardiolipins (CL). Using our chromatographic conditions, the following separation could be achieved: PC, PE and PG classes (two fatty acid chains on phospholipids) from 8.5 to 12 min and CL class (four fatty acid chains on phospholipids) from 18.8 to $20.5 \mathrm{~min}$. Some co-elution was still observed for isomers of phospholipids exhibiting different combinations of fatty acyl chains (e.g. PG 16:1/16:0 and PG 18:1_14:0, see ESM_1 Fig. S1) and for phospholipids consisted of fatty acyl chains showing two methylene and one more double bond (noted as DBE for double bond equivalent) than other phospholipids of the same class (e.g. PE 30:0, PE 32:1 and PE 34:2). Lipid identification was achieved thanks to the orthogonal MS dimension, more precisely from MS/MS data and accurate mass measurements.

Thus, 41 lipids were clearly identified in the membrane of PAK (see ESM_1: Tables S1, S2, and S3): 28 phospholipids (8 PGs, 13 PEs and 7 PCs) and 13 CLs. Please note that with our analytical conditions (i.e. buffered mobile phases), the cardiolipins were detected as singly 
242 charged species but not as doubly charged species-as previously described with other 243 analytical conditions [36]. The lipid annotation is based on the nomenclature of Liebisch et 244 al. [37].

245 To our knowledge, this study is the first one on the membrane lipids of the strain PAK 246 other studies were performed on the strains PAO1 and PA14 [9, 10]. No relevant differences

247 between the membrane lipids of the strains PAK, PAO1 and PA14 were observed.

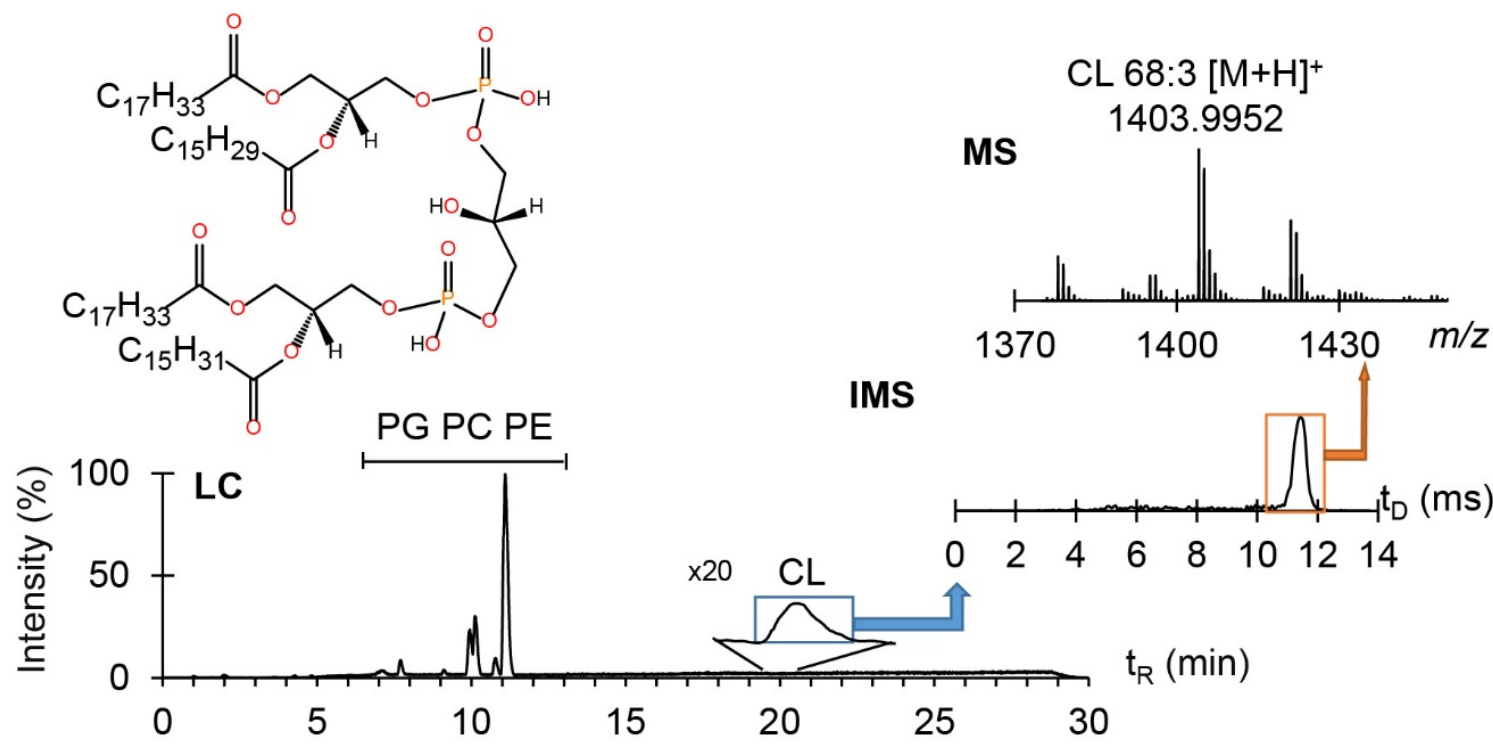

250 Fig. 1 Base Peak Chromatogram (BPC), extracted ion mobility spectrum and mass spectrum 251 from LC-IMS-MS analysis of PAK membrane extract. The enlarged retention time zone 252 corresponds to cardiolipins. The ion mobility spectrum was extracted for $\mathrm{CL} 68: 3(\mathrm{~m} / \mathrm{z}$ 253 1403.9952). The mass spectrum is obtained by integrating the ion mobility spectra from 10.5 $254 \mathrm{~ms}$ to $12.5 \mathrm{~ms}$. A possible structure for $\mathrm{m} / \mathrm{z} 1403.9952$ is given on the left.

${ }^{T W}{ }_{C C S}$ N2 determination, comparison with published CCS values and post-calibration correction Most of the CCS reported in the literature for phospholipids $(\mathrm{PL})$ have been obtained 258 using either a drift-tube IMS instrument $[15,20,38,39]$ or a TWIMS cell calibrated with polyalanine ions [17-19]. In the latter case, Hines et al. [20, 25] had previously 
260

261

262

263

264

265

266

demonstrated that the ${ }^{\mathrm{TW}} \mathrm{CCS}_{\mathrm{N} 2}$ determination of $\mathrm{PL}$ requires TWIMS cell calibration with $\mathrm{PL}$ calibrants. However, obtaining the most representative ${ }^{{ }^{T W}} \mathrm{CCS}_{\mathrm{N} 2}$ values would require to have lipid calibration curves for each chemical class present in the sample (PC, PE, PG or CL) and for each number of double bonds on the fatty acyl chains $(0,1$ or 2$)$.

Because of the lack of such calibrants, we chose to use a single calibrant to determine the CCS values of all the PAK membrane lipids. For this reason, we choose the dextran calibrant which covers the required $\mathrm{m} / \mathrm{z}$ and CCS ranges, in particular for CLs.

Please note that an extrapolated polyalanine calibration was considered as well, but for clarity, the following methodology will be described for the dextran calibration first. The calibration curves obtained with dextran (in both positive and negative modes) were then used for our PAK sample (see ESM_2). Thus, the ${ }^{\mathrm{TW}} \mathrm{CCS}_{\mathrm{N} 2}$ of $[\mathrm{M}+\mathrm{H}]^{+}$were measured for PEs, $\mathrm{PCs}$ and $\mathrm{CLs}$ in positive ion mode while the ${ }^{\mathrm{TW}} \mathrm{CCS}_{\mathrm{N} 2}$ of $[\mathrm{M}-\mathrm{H}]^{-}$were measured for PEs, PGs and CLs in negative ion mode. Triplicate of ${ }^{\mathrm{TW}} \mathrm{CCS}_{\mathrm{N} 2}$ measurements were carried out for each sample (in positive and negative ion mode) and gave repeatable CCS values $(0.1 \% \leq \% \mathrm{RSD} \leq$ $0.4 \%, n=3)$. However, when we compared our measured ${ }^{{ }^{T} W}{ }^{2} C_{\mathrm{N} 2}$ values with those published (5 PEs and 6 PCs inpositive mode, 6 PEs and 4 PGs in negative mode), shifts in CCS were systematically observed $(\Delta C C S \geq 2 \%)\left(E S M \_1:\right.$ Tables S4 and S5). This is also illustrated in Fig. 2a: the ex- perimental ${ }^{\mathrm{TW}} \mathrm{CCS}_{\mathrm{N} 2}$ values obtained after dextran calibration in positive ion mode (red squares) are significantly shifted towards higher CCS values compared with the lipid CCS values from the literature [20] (extrapolated black line).

In order to avoid this issue, we propose here a CCS correction strategy to reduce the shift due to the dextran calibration. The CCS correction strategy was carried out, using the IMS lipid calibrants (PEs and PCs, see ESM_2), by plotting correlation curves between their experimental ${ }^{\mathrm{TW}} \mathrm{CCS}_{\mathrm{N} 2}$ calibrated with dextran and their published ${ }^{\mathrm{DT}} \mathrm{CCS}_{\mathrm{N} 2}$ [20]. In both positive and negative ion mode, a linear regression was obtained with high coefficient of determination ( $R 2 \geq 0.999, E_{2}{ }_{-}$). This post-calibration correction was then applied to the ${ }^{\mathrm{TW}} \mathrm{CCS}_{\mathrm{N} 2}$ values of lipids present in PAK strain (red squares of Fig. 2b). Please note that previous work had shown that the fatty acyl chains of phospholipids extracted from $P$. aeruginosa can be different from the ones of eukaryotes - especially odd-chains which can 
289 be cyclopropylated or methylated $[9,40]$. However, considering the resolving power of

290

291 TWIMS, linear, cyclopropylated or methylated fatty acyl chain isomers would not be separated. Hence, we could use easily available phospholipid standards rather than bacterial phospholipids for the correction.

In parallel, as proof of concept for our correction strategy, we also determined ${ }^{\mathrm{TW}} \mathrm{CCS}_{\mathrm{N} 2}$ for PAK lipids using polyalanine or lipid calibration curves (see ESM_2). These calibration curves were extrapolated to higher CCS values in order to exceed those of CLs.

The experimental ${ }^{\mathrm{TW}} \mathrm{CCS}_{\mathrm{N} 2}$ for PAK lipids, using these extrapolated calibration curves, are reported in Fig. 2a as green (polyalanine cal) and blue (PL cal) points. One can notice that the CCS range of our ${ }^{\mathrm{TW}} \mathrm{CCS}_{\mathrm{N} 2}$ obtained with polyalanine calibration (ESM_1: Table S2) are consistent with the cardiolipins ${ }^{\mathrm{TW}} \mathrm{CCS}_{\mathrm{N} 2}$ of $[\mathrm{M}+2 \mathrm{~K}]^{2+}$ and $[\mathrm{M}-2 \mathrm{H}]^{2-}$ from Escherichia coli recently published by Hines et al. (CCS range of 380-425 $\AA^{2}$ ) [25]. The correction strategy, previously described for the ${ }^{\mathrm{TW}} \mathrm{CCS}_{\mathrm{N} 2}$ calibrated with dextran, was also applied for ${ }^{{ }^{\mathrm{W}}} \mathrm{CCS}_{\mathrm{N} 2}$ values calibrated with polyalanine (green points of Fig. $2 b$ ).

Figure $2 \mathrm{~b}$ shows that the correction strategy applied for ${ }^{\mathrm{TW}} \mathrm{CCS}_{\mathrm{N} 2}$ values calibrated by either dextran or polyalanine, and the ${ }^{\mathrm{TW}} \mathrm{CCS}_{\mathrm{N} 2}$ calibration - without correction - with PL, lead to convergent experimental ${ }^{\mathrm{T} w} \mathrm{CCS}_{\mathrm{N} 2}$ values. Moreover, for $\mathrm{CLs}$, these convergent ${ }^{\mathrm{TW}} \mathrm{CCS}_{\mathrm{N} 2}$ values are smaller than the extrapolated $\mathrm{PE} / \mathrm{PC}{ }^{\mathrm{DT}} \mathrm{CCS}_{\mathrm{N} 2}$ black line. This result suggests that cardiolipins are more compact (smaller ${ }^{\mathrm{TW}} \mathrm{CCS}_{\mathrm{N} 2}$ value) than any PE or PC which would have a similar $\mathrm{m} / \mathrm{z}$ value (extrapolated black line). This might be explained by the fact that cardiolipins are biosynthesized from a phosphatidylglycerol and a phosphatidic acid [41] which have smaller CCS values than PEs or PCs [15]. The details of all the ${ }^{\mathrm{TW}} \mathrm{CCS}_{\mathrm{N} 2}$ values we measured are reported in the supplementary information (ESM_1: Tables S1 to S3): ${ }^{\mathrm{TW}} \mathrm{CCS}_{\mathrm{N} 2}$ values using the three types of calibration (dextran (Table S1), polyalanine (Table S2) and lipids (Table S3)) and the two corrections (dextran corrected with lipids (Table S1) and polyalanine corrected with lipids (Table S2). 

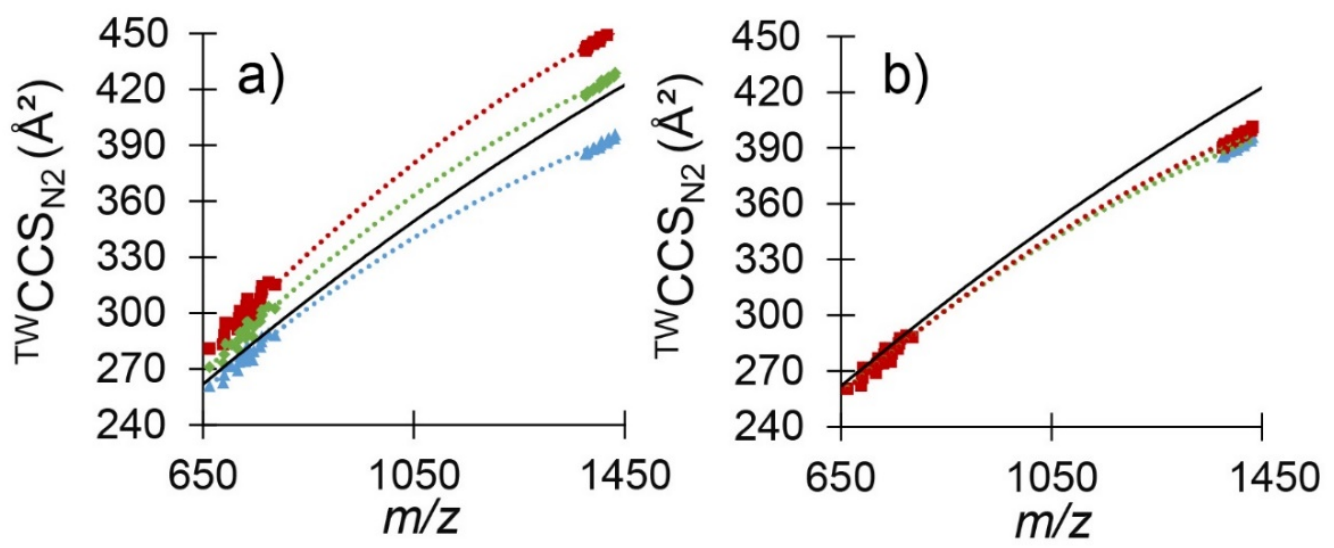

- PE/PC IMS standards extrapolated curve (literature ${ }^{\mathrm{DT}} \mathrm{CCS}_{\mathrm{N} 2}$ values)

PAK lipids ${ }^{\mathrm{TW}} \mathrm{CCS}_{\mathrm{N} 2}$ values calibrated with dextran

PAK lipids ${ }^{T W}{ }^{C C S} S_{\mathrm{N} 2}$ values calibrated with polyalanine

PAK lipids ${ }^{\mathrm{TW}} \mathrm{CCS}_{\mathrm{N} 2}$ values calibrated with PE/PC standards

317 Fig. $2{ }^{\mathrm{TW}} \mathrm{CCS}_{\mathrm{N} 2}$ plotted against $\mathrm{m} / \mathrm{z}$ for positive ions of PAK lipids. (a) represents ${ }^{\mathrm{TW}} \mathrm{CCS}_{\mathrm{N} 2}$ of PAK lipids before correction of the ${ }^{\mathrm{TW}} \mathrm{CCS}_{\mathrm{N} 2}$ values. (b) represents ${ }^{\mathrm{TW}} \mathrm{CCS}_{\mathrm{N} 2}$ of PAK lipids after the

In order to validate our correction strategy (calibration with dextran followed by a post-calibration correction with lipids, as mentioned above), the corrected ${ }^{\mathrm{TW}} \mathrm{CCS}_{\mathrm{N} 2}$ values were compared with the published ones. Note that several phospholipids (PEs, PGs and PCs) present in our sample had published CCS values (17 in positive mode and 16 in negative mode). On the other hand, CCS values of protonated and deprotonated prokaryote cardiolipins had never been reported. Considering that published CCS values from different ion mobility techniques have some disparities $(0.04 \% \leq \Delta \mathrm{CCS} \% \leq 3.84 \%$, ESM_1: Tables S6 and S7), our ${ }^{\mathrm{TW}} \mathrm{CCS}_{\mathrm{N} 2}$ are consistent with the CCS values from the literature, as reported in Table S5. One can note that the CCS disparities in the literature could be due to differences in lipid structures (e.g. double bond location and geometry cis/trans). This structural heterogeneity would give rise to small, but measurable, CCS difference [38]. 
335 In addition, one can observe that the correction strategy allows a shift reduction to less than $2 \%$ between our corrected ${ }^{\mathrm{TW}} \mathrm{CCS}_{\mathrm{N} 2}$ and those reported by Zhou et al. [15] and Hines et al.

337 [20], as shown in Table 1. Since such deviation is acceptable for inter-laboratory reproducibility, we can highlight the validation of the post-calibration correction strategy.

339 Furthermore, the ${ }^{\mathrm{TW}} \mathrm{CCS}_{\mathrm{N} 2}$ values of phospholipids extracted from PAK membrane are similar 340 to the CCS values of lipid standards from the literature; therefore, we can suppose that the 341 phospholipids in PAK have similar tridimensional structures in gas phase than the 342 phospholipids used by Zhou et al. and Hines et al. (synthetic standards) [15, 20]. Besides, a 343 similar decrease of the shift between our experimental ${ }^{{ }^{\mathrm{W}}}{ } \mathrm{CCS}_{\mathrm{N} 2}$ values and those of the 344 literature was observed for the experimental CCS values obtained by polyalanine calibration 345 and post-calibration lipid correction, as illustrated in Fig. 2 b. All comparisons with the 346 literature are given in ESM_1 Tables S4 and S5.

Table 1. Comparison of our experimental ${ }^{\mathrm{TW}} \mathrm{CCS}_{\mathrm{N} 2}$, from $\mathrm{PAK}$, with the published values. a and $\mathrm{b}$ correspond to relative shifts between our CCS and ${ }^{\mathrm{DT}} \mathrm{CCS}_{\mathrm{N} 2}$ from a: Zhou et al. (2017) [15] and b: Hines et al. (2016) [20], respectively.

\begin{tabular}{|c|c|c|c|c|c|c|}
\hline \multirow{3}{*}{ Lipid } & \multicolumn{6}{|c|}{ Positive ion mode $[\mathrm{M}+\mathrm{H}]^{+}$} \\
\hline & \multirow{2}{*}{\multicolumn{3}{|c|}{$\begin{array}{c}\text { Calibration using dextran } \\
{ }^{\mathrm{TW}} \mathrm{CCS}_{\mathrm{N} 2}\left(\AA^{2}\right) \Delta \mathrm{CCS}^{\mathrm{a}}(\%) \Delta \mathrm{CCS}^{\mathrm{b}}(\%)\end{array}$}} & \multicolumn{3}{|c|}{ After calibration correction } \\
\hline & & & & ${ }^{\mathrm{TW}} \mathrm{CCS}_{\mathrm{N} 2}\left(\AA^{2}\right)$ & $\Delta \operatorname{CCS}^{\mathrm{a}}(\%)$ & $\Delta \operatorname{CCS}^{\mathrm{b}}(\%)$ \\
\hline PC 32:0 & 307.6 & 8.0 & 8.9 & 282.0 & -1.0 & -0.2 \\
\hline PE 32:0 & 294.6 & 7.8 & 8.5 & 271.4 & -0.7 & 0.0 \\
\hline PE 34:0 & 301.0 & 7.5 & 8.5 & 276.6 & -1.2 & -0.3 \\
\hline PE 34:1 & 297.1 & 7.4 & 8.7 & 273.4 & -1.2 & 0.0 \\
\hline
\end{tabular}

Negative ion mode $[\mathrm{M}-\mathrm{H}]^{-}$

\begin{tabular}{|c|c|c|c|c|c|c|}
\hline \multirow{3}{*}{ Lipid } & \multicolumn{6}{|c|}{ Negative ion mode $[\mathrm{M}-\mathrm{H}]^{-}$} \\
\hline & \multicolumn{3}{|c|}{ Calibration using dextran } & \multicolumn{3}{|c|}{ After calibration correction } \\
\hline & ${ }^{\mathrm{TW}} \mathrm{CCS}_{\mathrm{N} 2}\left(\AA^{2}\right)$ & $\Delta \operatorname{CCS}^{\mathrm{a}}(\%)$ & $\Delta \operatorname{CCS}^{\mathrm{b}}(\%)$ & ${ }^{\mathrm{TW}} \mathrm{CCS}_{\mathrm{N} 2}\left(\AA^{2}\right)$ & $\Delta \operatorname{CCS}^{\mathrm{a}}(\%)$ & $\Delta \operatorname{CCS}^{\mathrm{b}}(\%)$ \\
\hline PE 32:0 & 274.4 & 5.6 & 5.8 & 257.1 & -1.1 & -0.9 \\
\hline PE 34:0 & 281.4 & 5.7 & 6.0 & 263.4 & -1.1 & -0.8 \\
\hline PE 34:1 & 279.5 & 5.5 & 5.7 & 261.6 & -1.3 & -1.1 \\
\hline
\end{tabular}


Table 2. ${ }^{\mathrm{TW}} \mathrm{CCS}_{\mathrm{N} 2}$ values, with dextran calibration and lipid correction, for phospholipids extracted from the membrane of PAK. extended to all the lipids of PAK. Table 2 reports the ${ }^{\mathrm{TW}} \mathrm{CCS}_{\mathrm{N} 2}$ values of lipids in PAK extracts which constitute new findings, in particular for CLs. Indeed, the ${ }^{\mathrm{TW}} \mathrm{CCS}_{\mathrm{N} 2}$ of $[\mathrm{M}+\mathrm{H}]^{+}$and $[\mathrm{M}-\mathrm{H}]$ - are determined for the first time for PAK cardiolipins (Table 2, ESM_1: Tables S1 to S3). As previously mentioned, the doubly charged cardiolipins were not detected since the ionization of the singly charged species was favored by our analytical conditions. In the case of phospholipids, we could verify that our corrected experimental CCS were consistent with those of phospholipids de- scribed in literature (ESM_1: Tables S4 and S5).

In total, $56{ }^{\mathrm{TW}} \mathrm{CCS}_{\mathrm{N} 2}$ values were measured and corrected, including 32 for positive ions and 24 for negative ions. Using the dextran calibration, the ${ }^{\mathrm{TW}} \mathrm{CCS}_{\mathrm{N} 2}$ range was from 303 $\AA^{2}$ to $455 \AA^{2}$ in positive mode and from $266 \AA^{2}$ to $418 \AA^{2}$ in negative mode, whereas when the dextran calibration was corrected, the ${ }^{\mathrm{TW}} \mathrm{CCS}_{\mathrm{N} 2}$ range was from $278 \AA^{2}$ to $401 \AA^{2}$ in positive mode and from $249 \AA^{2}$ to $387 \AA^{2}$ in negative mode. More precisely for cardiolipins, the ${ }^{\mathrm{TW}} \mathrm{CCS}_{\mathrm{N} 2}$ range was from $441 \AA^{2}$ to $455 \AA^{2}$ in positive mode and from $411 \AA^{2}$ to $418 \AA^{2}$ in negative mode, whereas when the dextran calibration was corrected, the ${ }^{\mathrm{TW}} \mathrm{CCS}_{\mathrm{N} 2}$ range was from $390 \AA^{2}$ to $401 \AA^{2}$ in positive mode and from $380 \AA^{2}$ to $387 \AA^{2}$ in negative mode. Moreover, for cardiolipins in negative mode, the ${ }^{\mathrm{TW}} \mathrm{CCS}_{\mathrm{N} 2}$ values were consistent with the first two ${ }^{\mathrm{DT}} \mathrm{CCS}_{\mathrm{N} 2}$ of $\mathrm{CL}$ (CL 72:6 and $\mathrm{CL}$ 72:7) described from bovine heart by Groessl et al. [38]. 


\begin{tabular}{cccc}
\hline \multirow{2}{*}{ Origin } & Lipid & $\begin{array}{c}{ }^{\mathrm{TW}} \mathrm{CCS}_{\mathrm{N} 2}\left(\AA^{2}\right) \\
\text { for }[\mathrm{M}+\mathrm{H}]^{+}\end{array}$ & $\begin{array}{c}{ }^{\mathrm{TW}} \mathrm{CCS}_{\mathrm{N} 2}\left(\AA^{2}\right) \\
\text { for }[\mathrm{M}-\mathrm{H}]^{-}\end{array}$ \\
\hline & PE 30:1 & 260.2 & 249.7 \\
& PE 33:1 & 271.0 & 258.7 \\
& PE 35:1 & $276.0^{*}$ & 264.9 \\
& PG 30:0 & nd & 258.3 \\
& PG 35:2 & nd & 269.7 \\
Phospholipids extracted & CL 66:3 & 390.1 & 380.4 \\
from the membrane of & CL 66:2 66:1 & 391.2 & 381.6 \\
& CL 67:3 & 391.9 & nd \\
& CL 67:2 & 392.8 & nd \\
& CL 68:4 & 393.7 & nd \\
& CL 68:3 & 394.0 & nd \\
& CL 68:2 & 395.7 & nd \\
& CL 69:4 & 397.4 & nd \\
& CL 69:3 & 396.7 & nd \\
& CL 69:2 & 398.3 & nd \\
& CL 70:4 & 399.0 & nd \\
& CL 70:3 & 399.4 & nd
\end{tabular}

These values are new to the literature, apart from the CCS noted with *. nd: not detected.

PAK lipid ${ }^{T w}{ }^{C C S} S_{N 2}$ vs $m / z$ correlation

Fig. 3 illustrates the correlation between the corrected ${ }^{\mathrm{TW}} \mathrm{CCS}_{\mathrm{N} 2}$ values and $m / z$ values 377 in negative mode: for all lipids in Fig. 3a and for PEs and PGs in Fig. 3b. As shown in Fig. 3a, a 378 polynomial fit for ${ }^{{ }^{\top W}} \mathrm{CCS}_{\mathrm{N} 2}$ plotted against $\mathrm{m} / \mathrm{z}$ in negative mode $(>0.999$ ) was observed. A 379 polynomial fit (> 0.99) was also observed for positive values (ESM_1: Fig. S9). By plotting ${ }^{\mathrm{TW}} \mathrm{CCS}_{\mathrm{N} 2}$ against $\mathrm{m} / \mathrm{z}$ for each chemical family, we can observe that PGs, PEs and CLs present

381 similar slopes.

382 In negative ion mode, deprotonated molecules of PEs and PGs present close ${ }^{\mathrm{TW}} \mathrm{CCS}_{\mathrm{N} 2}$ values 383 for a same $m / z$ range (Fig. $3 b$ ), also for PEs and PGs constituted of the same acyl chains. The 
384

385

386

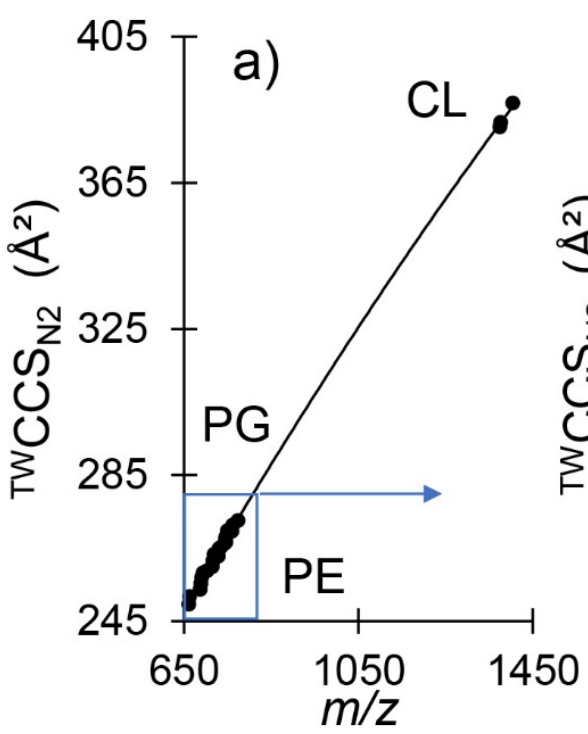
described $[15,28,42]$.

${ }^{\mathrm{TW}} \mathrm{CCS}_{\mathrm{N} 2}$ of PGs are slightly higher than the ones of the PEs (e.g. ${ }^{\mathrm{TW}} \mathrm{CCS}_{\mathrm{N} 2}(\mathrm{PG} 34: 1)=268.5 \AA^{2}>$ $\left.{ }^{\mathrm{TW}} \mathrm{CCS}_{\mathrm{N} 2}(\mathrm{PE} 34: 1)=261.6 \AA^{2}\right)$. A similar trend was observed for PEs and PCs, in positive mode, with $P C^{\prime} S^{T W}{ } C S_{N 2}$ being slightly higher than the ones of the PEs (ESM_1: Fig. S9).

Moreover, as shown in Fig. 3b, we can make several observations. First, as previously described by Jackson et al. [28], the CCS linearly decreases when the number of doublebonds increases in the fatty acyl chains for definite chain lengths (e.g. C32:0, C32:1 and C32:2). Secondly, the slope observed from this linear pattern was identical for every chemical classes, leading to a symmetrical figure, as described by Leaptrot et al [39]. Thirdly, for positive ions (ESM_1: Fig. S9), CCS values of phospholipids with odd number of carbon atoms in the fatty acyl chains and with 0, 1 or 2 DBE were closer than the CCS values of phospholipids with even number of carbon atoms. All of these observations could be explained by the folding of the fatty acyl chain with the increase of the DBE, as previously

Fig. $3{ }^{\mathrm{TW}} \mathrm{CCS}_{\mathrm{N} 2}$ values plotted against $\mathrm{m} / \mathrm{z}$ for negative ions. 3a represents values for every class of phospholipids, whereas $3 \mathrm{~b}$ only represents values for PEs and PGs. $3 \mathrm{~b}$ was inspired from the Fig. 4 from Zhou et al (2017) [15]. PGs are represented by squares, PEs by diamonds. $X$ refers to the number of double-bonds on the fatty acid moiety of the phospholipid which can be 0,1 or 2 for PEs and PGs. 


\section{CONCLUSION}

404

In this study, new knowledge about the membrane phospholipids of $P$. aeruginosa was

405

406

407

408

409

410

411

412

413

414

415

416

\section{FUNDING INFORMATION}

418 The authors gratefully acknowledge European Regional Development Fund (ERDF, no. HN0001343), Labex SynOrg (ANR-11-LABX-0029) and Région Normandie for their financial 420 support.

\section{CONFLICT OF INTEREST}

The authors declare that they have no conflict of interest. 
426

427 1. Obritsch MD, Fish DN, MacLaren R, Jung R (2005) Nosocomial Infections Due to Multidrug-Resistant

428 Pseudomonas aeruginosa: Epidemiology and Treatment Options. PHARMACOTHERAPY 25 (10):11

429 2. Curran CS, Bolig T, Torabi-Parizi P (2018) Mechanisms and Targeted Therapies for Pseudomonas aeruginosa 430 Lung Infection. American journal of respiratory and critical care medicine 197 (6):708-727. 431 doi:10.1164/rccm.201705-1043SO

432 3. Tacconelli $E$, et al. (2018) Discovery, research, and development of new antibiotics: the WHO priority list of 433 antibiotic-resistant bacteria and tuberculosis. The Lancet Infectious Diseases 18 (3):318-327. 434 doi:10.1016/s1473-3099(17)30753-3

435 4. Bassetti M, Vena A, Croxatto A, Righi E, Guery B (2018) How to manage Pseudomonas aeruginosa infections. 436 Drugs Context 7:212527. doi:10.7573/dic.212527

437 5. Escriba PV (2006) Membrane-lipid therapy: a new approach in molecular medicine. Trends Mol Med 12 438 (1):34-43. doi:10.1016/j.molmed.2005.11.004

439 6. Gaviard C, Jouenne T, Hardouin J (2018) Proteomics of Pseudomonas aeruginosa: the increasing role of post440 translational modifications. Expert Rev Proteomics 15 (9):757-772. doi:10.1080/14789450.2018.1516550

7. Kamath KS, Krisp C, Chick J, Pascovici D, Gygi SP, Molloy MP (2017) Pseudomonas aeruginosa Proteome under Hypoxic Stress Conditions Mimicking the Cystic Fibrosis Lung. Journal of proteome research 16 (10):3917-3928. doi:10.1021/acs.jproteome.7b00561

8. Hare NJ, Solis N, Harmer C, Marzook NB, Rose B, Harbour C, Crossett B, Manos J, Cordwell SJ (2012) Proteomic profiling of Pseudomonas aeruginosa AES-1R, PAO1 and PA14 reveals potential virulence determinants associated with a transmissible cystic fibrosis-associated strain. BMC Microbiol 12:16. doi:10.1186/1471-2180-12-16

9. Benamara H, Rihouey C, Abbes I, Mlouka MAB, Hardouin J, Jouenne T, Alexandre S (2014) Characterization of Membrane Lipidome Changes in Pseudomonas aeruginosa during Biofilm Growth on Glass Wool. Plos One 9 (9):9. doi:10.1371/journal.pone.0108478.g001

10. Benamara H, Rihouey C, Jouenne T, Alexandre S (2011) Impact of the biofilm mode of growth on the inner membrane phospholipid composition and lipid domains in Pseudomonas aeruginosa. Biochim Biophys Acta 1808 (1):98-105. doi:10.1016/j.bbamem.2010.09.004

11. Ewing MA, Glover MS, Clemmer DE (2016) Hybrid ion mobility and mass spectrometry as a separation tool. J Chromatogr A 1439:3-25. doi:10.1016/j.chroma.2015.10.080

12. Cumeras R, Figueras E, Davis CE, Baumbach JI, Gracia I (2015) Review on ion mobility spectrometry. Part 1: current instrumentation. Analyst 140 (5):1376-1390. doi:10.1039/c4an01100g

13. Gabelica V, Marklund E (2018) Fundamentals of ion mobility spectrometry. Curr Opin Chem Biol 42:51-59. doi:10.1016/j.cbpa.2017.10.022

14. Plante PL, Francovic-Fontaine E, May JC, McLean JA, Baker ES, Laviolette F, Marchand M, Corbeil J (2019) Predicting Ion Mobility Collision Cross-Sections Using a Deep Neural Network: DeepCCS. Anal Chem 91 (8):5191-5199. doi:10.1021/acs.analchem.8b05821

15. Zhou Z, Tu J, Xiong X, Shen X, Zhu ZJ (2017) LipidCCS: Prediction of Collision Cross-Section Values for Lipids with High Precision To Support Ion Mobility-Mass Spectrometry-Based Lipidomics. Analytical chemistry 89 (17):9559-9566. doi:10.1021/acs.analchem.7b02625 
466

467

468 Deciphering drift time measurements from travelling wave ion mobility spectrometry-mass spectrometry studies. European journal of mass spectrometry 15 (2):113-130. doi:10.1255/ejms.947

17. Paglia G, Astarita G (2017) Metabolomics and lipidomics using traveling-wave ion mobility-mass spectrometry. Nat Protoc 12 (4):17. doi:10.1038/nprot.2017.013

18. Paglia G, Kliman M, Claude E, Geromanos S, Astarita G (2015) Applications of ion-mobility mass spectrometry for lipid analysis. Anal Bioanal Chem 407:12

19. Paglia G, Williams JP, Menikarachchi L, Thompson JW, Tyldesley-Worster R, Halldorsson S, Rolfsson O, Moseley A, Grant D, Langridge J, Palsson BO, Astarita G (2014) lon mobility derived collision cross sections to support metabolomics applications. Analytical chemistry 86 (8):3985-3993. doi:10.1021/ac500405x

20. Hines KM, May JC, McLean JA, Xu L (2016) Evaluation of Collision Cross Section Calibrants for Structural Analysis of Lipids by Traveling Wave Ion Mobility-Mass Spectrometry. Analytical chemistry 88 (14):7329-7336. doi:10.1021/acs.analchem.6b01728

21. Levy AJ, Oranzi NR, Ahmadireskety A, Kemperman RHJ, Wei MS, Yost RA (2019) Recent progress in metabolomics using ion mobility-mass spectrometry. TrAC Trends in Analytical Chemistry 116:274-281. doi:10.1016/j.trac.2019.05.001

22. Tejada-Casado C, Hernandez-Mesa M, Monteau F, Lara FJ, Olmo-Iruela MD, Garcia-Campana AM, Le Bizec B, Dervilly-Pinel G (2018) Collision cross section (CCS) as a complementary parameter to characterize human and veterinary drugs. Anal Chim Acta 1043:52-63. doi:10.1016/j.aca.2018.09.065

23. May JC, Morris CB, McLean JA (2017) Ion Mobility Collision Cross Section Compendium. Analytical chemistry 89 (2):1032-1044. doi:10.1021/acs.analchem.6b04905

24. Schrimpe-Rutledge AC, Sherrod SD, McLean JA (2018) Improving the discovery of secondary metabolite natural products using ion mobility-mass spectrometry. Curr Opin Chem Biol 42:160-166. doi:10.1016/j.cbpa.2017.12.004

25. Hines KM, Xu L (2019) Lipidomic consequences of phospholipid synthesis defects in Escherichia coli revealed by HILIC-ion mobility-mass spectrometry. Chemistry and physics of lipids 219:15-22. doi:10.1016/j.chemphyslip.2019.01.007

26. Zheng X, Aly NA, Zhou Y, Dupuis KT, Bilbao A, Paurus VL, Orton DJ, Wilson R, Payne SH, Smith RD, Baker ES (2017) A structural examination and collision cross section database for over 500 metabolites and xenobiotics using drift tube ion mobility spectrometry. Chem Sci 8 (11):7724-7736. doi:10.1039/c7sc03464d

27. Ridenour WB, Kliman M, McLean JA, Caprioli RM (2010) Structural characterization of phospholipids and peptides directly from tissue sections by MALDI traveling-wave ion mobility-mass spectrometry. Analytical chemistry 82 (5):1881-1889. doi:10.1021/ac9026115

28. Jackson SN, Ugarov M, Post JD, Egan T, Langlais D, Schultz JA, Woods AS (2008) A study of phospholipids by ion mobility TOFMS. Journal of the American Society for Mass Spectrometry 19 (11):1655-1662. doi:10.1016/j.jasms.2008.07.005

29. Harris RA, Leaptrot KL, May JC, McLean JA (2019) New frontiers in lipidomics analyses using structurally selective ion mobility-mass spectrometry. TrAC-Trend Anal Chem 116:316-323. doi:10.1016/j.trac.2019.03.031

30. Hinz C, Liggi S, Griffin JL (2018) The potential of Ion Mobility Mass Spectrometry for high-throughput and high-resolution lipidomics. Curr Opin Chem Biol 42:42-50. doi:10.1016/j.cbpa.2017.10.018

31. Bligh EG, Dyer WJ (1959) A rapid method of total lipid extraction and purification. Can J Biochem Physiol 37 (8):7 
32. Hofmann J, Struwe WB, Scarff CA, Scrivens JH, Harvey DJ, Pagel K (2014) Estimating collision cross sections of negatively charged $\mathrm{N}$-glycans using traveling wave ion mobility-mass spectrometry. Analytical chemistry 86 (21):10789-10795. doi:10.1021/ac5028353

33. Pagel K, Harvey DJ (2013) Ion mobility-mass spectrometry of complex carbohydrates: collision cross sections of sodiated N-linked glycans. Analytical chemistry 85 (10):5138-5145. doi:10.1021/ac400403d

34. Bush MF, Campuzano ID, Robinson CV (2012) lon mobility mass spectrometry of peptide ions: effects of drift gas and calibration strategies. Analytical chemistry 84 (16):7124-7130. doi:10.1021/ac3014498

35. Domalain V, Hubert-Roux M, Tognetti V, Joubert L, Lange CM, Rouden J, Afonso C (2014) Enantiomeric differentiation of aromatic amino acids using traveling wave ion mobility-mass spectrometry. Chem Sci 5 (8):3234-3239. doi:10.1039/c4sc00443d

36. Garrett TA, Kordestani R, Raetz CRH (2007) Quantification of Cardiolipin by Liquid ChromatographyElectrospray Ionization Mass Spectrometry. 433:213-230. doi:10.1016/s0076-6879(07)33012-7

37. Liebisch G, Vizcaino JA, Kofeler H, Trotzmuller M, Griffiths WJ, Schmitz G, Spener F, Wakelam MJ (2013) Shorthand notation for lipid structures derived from mass spectrometry. Journal of lipid research 54 (6):15231530. doi:10.1194/jlr.M033506

38. GroessI M, Graf S, Knochenmuss R (2015) High resolution ion mobility-mass spectrometry for separation and identification of isomeric lipids. Analyst 140 (20):6904-6911. doi:10.1039/c5an00838g

39. Leaptrot KL, May JC, Dodds JN, McLean JA (2019) Ion mobility conformational lipid atlas for high confidence lipidomics. Nature communications 10 (1):985. doi:10.1038/s41467-019-08897-5

40. Chao J, Wolfaardt GM, Arts MT (2010) Characterization of Pseudomonas aeruginosa fatty acid profiles in biofilms and batch planktonic cultures. Can J Microbiol 56 (12):1028-1039. doi:10.1139/W10-093

41. Schlame M (2008) Cardiolipin synthesis for the assembly of bacterial and mitochondrial membranes. Journal of lipid research 49 (8):1607-1620. doi:10.1194/jlr.R700018-JLR200

42. Kim HI, Kim H, Pang ES, Ryu EK, Beegle LW, Loo JA, Goddard WA, Kanik I (2009) Structural characterization of unsaturated phosphatidylcholines using traveling wave ion mobility spectrometry. Analytical chemistry 81 (20):8289-8297. doi:10.1021/ac900672a

43. El Khoury M, Swain J, Sautrey G, Zimmermann L, Van Der Smissen P, Décout J-L, Mingeot-Leclercq M-P (2017) Targeting Bacterial Cardiolipin Enriched Microdomains: An Antimicrobial Strategy Used by Amphiphilic Aminoglycoside Antibiotics. Sci Rep 7 (1). doi:10.1038/s41598-017-10543-3 


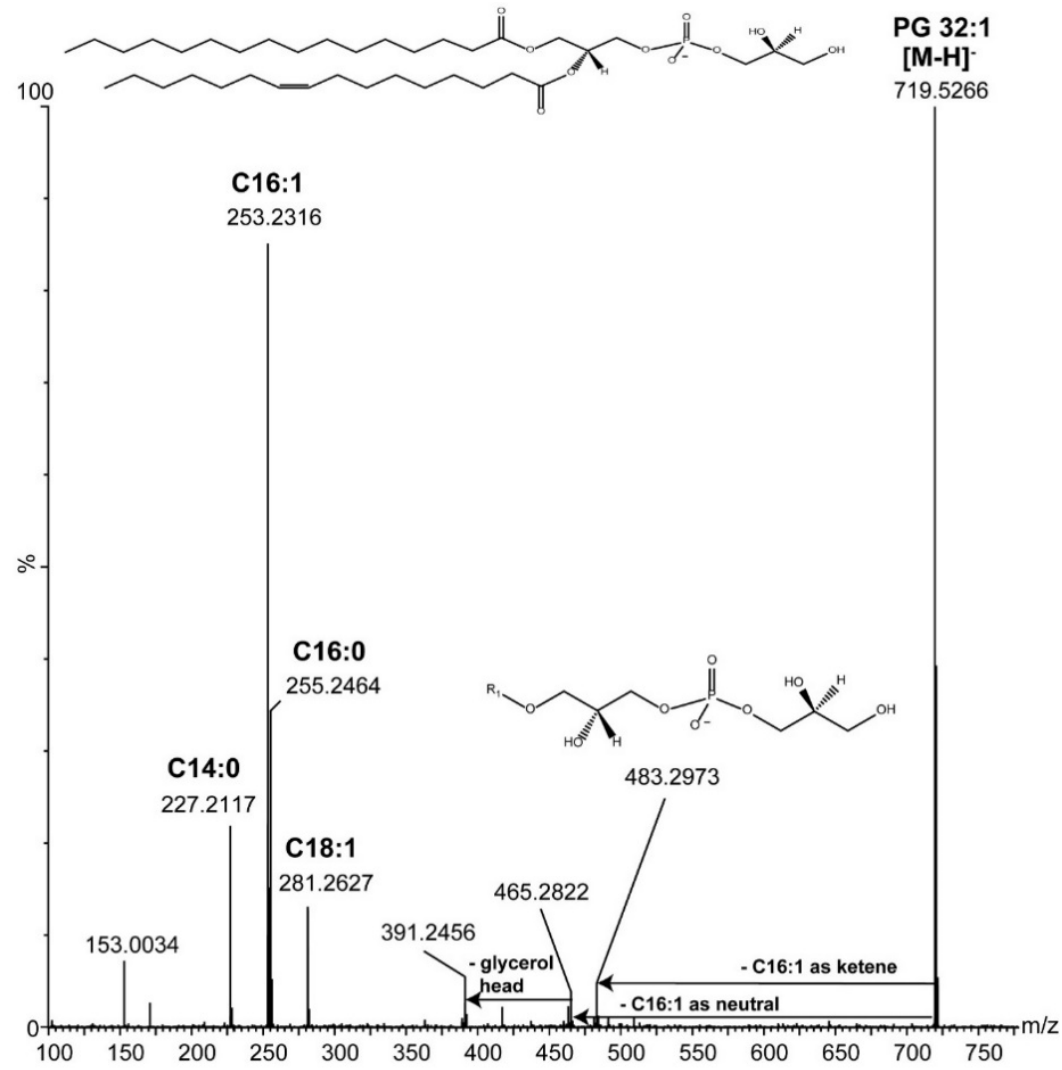

540 Fig S1. MS/MS Spectra of PG 32:1. A possible structure of the most abundant isomer is given

541 (cis or trans isomerism cannot be determined with this experiment). The ion of $\mathrm{m} / \mathrm{z}$

542153.0034 corresponds to the Glycerol-3-phosphate ion with loss of $\mathrm{H}_{2} \mathrm{O}$. The $[\mathrm{M}-\mathrm{H}]^{-}$of the

543 fatty acyl chains show the presence the isomers PG 16:0_16:1 and PG 14:0_18:1. Knowing

544 that the loss of $s n-2$ is favoured, since ions of $\mathrm{m} / z$ 483.2973, 465.2822, 391.2456 and

545253.2316 are the most abundant, we can conclude that for PG 16:0/16:1, the most abundant

546 isomer, the 16:0 is on position $s n-1$ and the $16: 1$ is on position $s n-2$.

547 Structural elucidation was performed according to Hsu F-F, Turk J (2009) Electrospray

548 Ionization with Low-energy Collisionally Activated Dissociation Tandem Mass Spectrometry 549 of Glycerophospholipids: Mechanisms of Fragmentation and Structural Characterization. J

550 Chromatogr B Analyt Technol Biomed Life Sci 877 (26):22. 
Table S2 ${ }^{\mathrm{TW}} \mathrm{CCS}_{\mathrm{N} 2}$ values calibrated with dextran for the membrane lipids of PAK

\begin{tabular}{|c|c|c|c|c|c|c|c|c|c|c|c|}
\hline \multirow{2}{*}{$\begin{array}{c}\text { membrane } \\
\text { lipids of PAK }\end{array}$} & \multirow[b]{2}{*}{ Formula } & \multicolumn{5}{|c|}{ Positive ions } & \multicolumn{5}{|c|}{ Negative ions } \\
\hline & & ion & $m / z$ & $\begin{array}{l}{ }^{\mathrm{TW}} \mathrm{CCS}_{\mathrm{N} 2} \\
\text { without } \\
\text { corrertion }\end{array}$ & $\begin{array}{c}{ }^{\mathrm{TW}} \mathrm{CCS}_{\mathrm{N} 2} \\
\text { \%RSD }\end{array}$ & $\begin{array}{c}\text { corrected } \\
{ }_{\mathrm{TW}} \mathrm{CCS}_{\mathrm{N} 2} \\
\left(\AA^{2} \mid\right. \\
\end{array}$ & ion & $m / z$ & $\begin{array}{l}{ }^{\mathrm{TW}} \mathrm{CCS}_{\mathrm{N} 2} \\
\text { without } \\
\text { correction }\end{array}$ & $\begin{array}{c}{ }^{\mathrm{TW}} \mathrm{CCS}_{\mathrm{N} 2} \\
\text { \%RSD }\end{array}$ & $\begin{array}{c}\text { corrected } \\
{ }^{\mathrm{TW}} \mathrm{CCS}_{\mathrm{N} 2} \\
\left(\AA^{2}\right) \\
\end{array}$ \\
\hline PC 32:1 & $\mathrm{C}_{40} \mathrm{H}_{78} \mathrm{NO}_{8} \mathrm{P}$ & {$[\mathrm{M}+\mathrm{H}]^{+}$} & 732.553 & 303.6 & 0.1 & 278.7 & & & & & \\
\hline PC 32:0 & $\mathrm{C}_{40} \mathrm{H}_{80} \mathrm{NO}_{8} \mathrm{P}$ & {$[\mathrm{M}+\mathrm{H}]^{+}$} & 734.569 & 307.6 & 0.1 & 282.0 & & & & & \\
\hline PC 34:2 & $\mathrm{C}_{42} \mathrm{H}_{82} \mathrm{NO}_{8} \mathrm{P}$ & {$[\mathrm{M}+\mathrm{H}]^{+}$} & 758.569 & 307.5 & 0.1 & 281.9 & & & & & \\
\hline PC 34:1 & $\mathrm{C}_{42} \mathrm{H}_{82} \mathrm{NO}_{8} \mathrm{P}$ & {$[\mathrm{M}+\mathrm{H}]^{+}$} & 760.585 & 311.0 & 0.1 & 284.7 & & & & & \\
\hline PC 34:0 & $\mathrm{C}_{42} \mathrm{H}_{84} \mathrm{NO}_{8} \mathrm{P}$ & {$[\mathrm{M}+\mathrm{H}]^{+}$} & 762.600 & 314.2 & 0.4 & 287.3 & & & & & \\
\hline PC 35:1 & $\mathrm{C}_{43} \mathrm{H}_{84} \mathrm{NO}_{8} \mathrm{P}$ & {$[\mathrm{M}+\mathrm{H}]+$} & 774.600 & 316.3 & 0.1 & 289.0 & & & & & \\
\hline PC 36:2 & $\mathrm{C}_{42} \mathrm{H}_{82} \mathrm{NO}_{8} \mathrm{P}$ & {$[\mathrm{M}+\mathrm{H}]^{+}$} & 786.600 & 315.1 & 0.1 & 288.1 & & & & & \\
\hline PE 30:1 & $\mathrm{C}_{35} \mathrm{H}_{68} \mathrm{NO}_{8} \mathrm{P}$ & {$[\mathrm{M}+\mathrm{H}]^{+}$} & 662.475 & 280.8 & 0.1 & 260.2 & {$[\mathrm{M}-\mathrm{H}]^{-}$} & 660.461 & 266.3 & 0.1 & 249.7 \\
\hline PE 30:0 & $\mathrm{C}_{35} \mathrm{H}_{70} \mathrm{NO}_{8} \mathrm{P}$ & & & & & & {$[\mathrm{M}-\mathrm{H}]^{-}$} & 662.476 & 268.6 & 0.1 & 251.8 \\
\hline PE 32:2 & $\mathrm{C}_{37} \mathrm{H}_{70} \mathrm{NO}_{8} \mathrm{P}$ & {$[\mathrm{M}+\mathrm{H}]^{+}$} & 688.491 & 283.2 & 0.1 & 262.2 & {$[\mathrm{M}-\mathrm{H}]^{-}$} & 686.476 & 270.7 & 0.2 & 253.7 \\
\hline PE 32:1 & $\mathrm{C}_{37} \mathrm{H}_{72} \mathrm{NO}_{8} \mathrm{P}$ & {$[\mathrm{M}+\mathrm{H}]^{+}$} & 690.506 & 288.3 & 0.1 & 266.3 & {$[\mathrm{M}-\mathrm{H}]^{-}$} & 688.492 & 272.6 & 0.1 & 255.4 \\
\hline PE 32:0 & $\mathrm{C}_{37} \mathrm{H}_{74} \mathrm{NO}_{8} \mathrm{P}$ & {$[\mathrm{M}+\mathrm{H}]^{+}$} & 692.522 & 294.6 & 0.0 & 271.4 & {$[\mathrm{M}-\mathrm{H}]^{-}$} & 690.507 & 274.4 & 0.1 & 257.1 \\
\hline PE 33:1 & $\mathrm{C}_{38} \mathrm{H}_{74} \mathrm{NO}_{8} \mathrm{P}$ & {$[\mathrm{M}+\mathrm{H}]^{+}$} & 704.522 & 294.1 & 0.1 & 271.0 & {$[\mathrm{M}-\mathrm{H}]^{-}$} & 702.507 & 276.3 & 0.1 & 258.7 \\
\hline PE 34:2 & $\mathrm{C}_{39} \mathrm{H}_{73} \mathrm{NO}_{8} \mathrm{P}$ & {$[\mathrm{M}+\mathrm{H}]^{+}$} & 716.522 & 291.4 & 0.1 & 268.8 & {$[\mathrm{M}-\mathrm{H}]^{-}$} & 714.507 & 277.7 & 0.1 & 260.0 \\
\hline PE 34:1 & $\mathrm{C}_{37} \mathrm{H}_{76} \mathrm{NO}_{8} \mathrm{P}$ & {$[\mathrm{M}+\mathrm{H}]^{+}$} & 718.538 & 297.1 & 0.1 & 273.4 & {$[\mathrm{M}-\mathrm{H}]^{-}$} & 716.523 & 279.5 & 0.0 & 261.6 \\
\hline PE 34:0 & $\mathrm{C}_{39} \mathrm{H}_{78} \mathrm{NO}_{8} \mathrm{P}$ & {$[\mathrm{M}+\mathrm{H}]^{+}$} & 720.553 & 301.0 & 0.1 & 276.6 & {$[\mathrm{M}-\mathrm{H}]^{-}$} & 718.539 & 281.4 & 0.1 & 263.4 \\
\hline PE 35:2 & $\mathrm{C}_{40} \mathrm{H}_{76} \mathrm{NO}_{8} \mathrm{P}$ & {$[\mathrm{M}+\mathrm{H}]^{+}$} & 730.538 & 297.8 & 0.1 & 274.0 & {$[\mathrm{M}-\mathrm{H}]^{-}$} & 728.523 & 280.9 & 0.1 & 262.9 \\
\hline PE 35:1 & $\mathrm{C}_{40} \mathrm{H}_{78} \mathrm{NO}_{8} \mathrm{P}$ & {$[\mathrm{M}+\mathrm{H}]+$} & 732.553 & 300.3 & 0.1 & 276.0 & {$[\mathrm{M}-\mathrm{H}]-$} & 730.539 & 283.2 & 0.0 & 264.9 \\
\hline PE 36:2 & $\mathrm{C}_{41} \mathrm{H}_{78} \mathrm{NO}_{8} \mathrm{P}$ & {$[\mathrm{M}+\mathrm{H}]^{+}$} & 744.553 & 298.8 & 0.1 & 274.8 & {$[\mathrm{M}-\mathrm{H}]^{-}$} & 742.539 & 284.6 & 0.1 & 266.2 \\
\hline PE 36:1 & $\mathrm{C}_{41} \mathrm{H}_{80} \mathrm{NO}_{8} \mathrm{P}$ & {$[\mathrm{M}+\mathrm{H}]+$} & 746.569 & 304.4 & 0.1 & 279.3 & [M-H]- & 744.554 & 286.4 & 0.1 & 267.9 \\
\hline
\end{tabular}




\begin{tabular}{|c|c|c|c|c|c|c|c|c|c|c|c|}
\hline \multirow[b]{2}{*}{$\begin{array}{l}\text { membrane } \\
\text { lipids of } \\
\text { PAK }\end{array}$} & \multirow[b]{2}{*}{ Formula } & \multicolumn{5}{|c|}{ Positive ions } & \multicolumn{5}{|c|}{ Negative ions } \\
\hline & & ion & $m / z$ & $\begin{array}{l}{ }^{\mathrm{TW}} \mathrm{CCS}_{\mathrm{N} 2} \\
\text { without } \\
\text { correction }\end{array}$ & $\begin{array}{c}{ }^{\mathrm{TW}} \mathrm{CCS}_{\mathrm{N} 2} \\
\% \mathrm{RSD}\end{array}$ & $\begin{array}{c}\text { corrected } \\
{ }^{\mathrm{TW}} \mathrm{CCS}_{\mathrm{N} 2}\left(\AA^{2}\right)\end{array}$ & ion & $m / z$ & $\begin{array}{l}{ }^{\mathrm{TW}} \mathrm{CCS}_{\mathrm{N} 2} \\
\text { without } \\
\text { correction }\end{array}$ & $\begin{array}{l}{ }^{\mathrm{TW}} \mathrm{CCS}_{\mathrm{N} 2} \\
\% \mathrm{RSD}\end{array}$ & $\begin{array}{c}\text { corrected } \\
{ }^{\mathrm{Tw}} \mathrm{CCS}_{\mathrm{N} 2} \\
\left(\AA^{2}\right) \\
\end{array}$ \\
\hline PG 30:0 & $\mathrm{C}_{36} \mathrm{H}_{71} \mathrm{O}_{10} \mathrm{P}$ & & & & & & [M-H]- & 693.4712 & 275.8 & 0.1 & 258.3 \\
\hline PG 32:1 & $\mathrm{C}_{38} \mathrm{H}_{71} \mathrm{O}_{10} \mathrm{P}$ & & & & & & {$[\mathrm{M}-\mathrm{H}]^{-}$} & 719.4869 & 281.4 & 0.1 & 263.4 \\
\hline PG 33:1 & $\mathrm{C}_{39} \mathrm{H}_{75} \mathrm{O}_{10} \mathrm{P}$ & & & & & & {$[\mathrm{M}-\mathrm{H}]^{-}$} & 733.5025 & 283.5 & 0.1 & 265.3 \\
\hline PG 34:2 & $\mathrm{C}_{40} \mathrm{H}_{75} \mathrm{O}_{10} \mathrm{P}$ & & & & & & {$[\mathrm{M}-\mathrm{H}]^{-}$} & 745.5025 & 285.1 & 0.1 & 266.6 \\
\hline PG 34:1 & $\mathrm{C}_{40} \mathrm{H}_{77} \mathrm{O}_{10} \mathrm{P}$ & & & & & & {$[\mathrm{M}-\mathrm{H}]^{-}$} & 747.5182 & 287.1 & 0.1 & 268.5 \\
\hline PG 35:2 & $\mathrm{C}_{40} \mathrm{H}_{75} \mathrm{O}_{10} \mathrm{P}$ & & & & & & {$[\mathrm{M}-\mathrm{H}]^{-}$} & 759.5182 & 288.5 & 0.1 & 269.7 \\
\hline PG 35:1 & $\mathrm{C}_{40} \mathrm{H}_{77} \mathrm{O}_{10} \mathrm{P}$ & & & & & & {$[\mathrm{M}-\mathrm{H}]^{-}$} & 761.5338 & 290.2 & 0.1 & 271.3 \\
\hline PG 36:2 & $\mathrm{C}_{42} \mathrm{H}_{79} \mathrm{O}_{10} \mathrm{P}$ & & & & & & {$[\mathrm{M}-\mathrm{H}]^{-}$} & 773.5338 & 291.7 & 0.1 & 272.6 \\
\hline CL 66:3 & $\mathrm{C}_{75} \mathrm{H}_{140} \mathrm{O}_{17} \mathrm{P}_{2}$ & {$[\mathrm{M}+\mathrm{H}]^{+}$} & 1375.963 & 441.0 & 0.2 & 390.1 & {$[\mathrm{M}-\mathrm{H}]^{-}$} & 1373.949 & 411.2 & 0.3 & 380.4 \\
\hline CL 66:2 & $\mathrm{C}_{75} \mathrm{H}_{142} \mathrm{O}_{17} \mathrm{P}_{2}$ & {$[\mathrm{M}+\mathrm{H}]^{+}$} & 1377.979 & 442.3 & 0.0 & 391.2 & {$[\mathrm{M}-\mathrm{H}]^{-}$} & 1375.965 & 412.5 & 0.4 & 381.6 \\
\hline CL 66:1 & $\mathrm{C}_{75} \mathrm{H}_{144} \mathrm{O}_{17} \mathrm{P}_{2}$ & {$[\mathrm{M}+\mathrm{H}]^{+}$} & 1379.995 & 443.2 & 0.1 & 391.9 & & & & & \\
\hline CL 67:3 & $\mathrm{C}_{76} \mathrm{H}_{142} \mathrm{O}_{17} \mathrm{P}_{2}$ & {$[\mathrm{M}+\mathrm{H}]^{+}$} & 1389.979 & 444.4 & 0.2 & 392.8 & & & & & \\
\hline CL 67:2 & $\mathrm{C}_{76} \mathrm{H}_{144} \mathrm{O}_{17} \mathrm{P}_{2}$ & {$[\mathrm{M}+\mathrm{H}]^{+}$} & 1391.995 & 445.4 & 0.2 & 393.7 & & & & & \\
\hline CL 68:4 & $\mathrm{C}_{77} \mathrm{H}_{142} \mathrm{O}_{17} \mathrm{P}_{2}$ & {$[\mathrm{M}+\mathrm{H}]^{+}$} & 1401.979 & 445.8 & 0.2 & 394.0 & & & & & \\
\hline CL 68:3 & $\mathrm{C}_{77} \mathrm{H}_{144} \mathrm{O}_{17} \mathrm{P}_{2}$ & {$[\mathrm{M}+\mathrm{H}]^{+}$} & 1403.995 & 447.9 & 0.1 & 395.7 & & & & & \\
\hline CL 68:2 & $\mathrm{C}_{77} \mathrm{H}_{146} \mathrm{O}_{17} \mathrm{P}_{2}$ & {$[\mathrm{M}+\mathrm{H}]^{+}$} & 1406.010 & 450.1 & 0.2 & 397.4 & {$[\mathrm{M}-\mathrm{H}]^{-}$} & 1403.996 & 418.4 & 0.3 & 386.9 \\
\hline CL 69:4 & $\mathrm{C}_{78} \mathrm{H}_{144} \mathrm{O}_{17} \mathrm{P}_{2}$ & {$[\mathrm{M}+\mathrm{H}]+$} & 1415.995 & 449.2 & 0.2 & 396.7 & & & & & \\
\hline CL 69:3 & $\mathrm{C}_{78} \mathrm{H}_{146} \mathrm{O}_{17} \mathrm{P}_{2}$ & {$[\mathrm{M}+\mathrm{H}]^{+}$} & 1418.010 & 451.1 & 0.2 & 398.3 & & & & & \\
\hline CL 69:2 & $\mathrm{C}_{78} \mathrm{H}_{148} \mathrm{O}_{17} \mathrm{P}_{2}$ & {$[\mathrm{M}+\mathrm{H}]^{+}$} & 1420.026 & 452.0 & 0.1 & 399.0 & & & & & \\
\hline CL 70:4 & $\mathrm{C}_{79} \mathrm{H}_{146} \mathrm{O}_{17} \mathrm{P}_{2}$ & {$[\mathrm{M}+\mathrm{H}]+$} & 1430.010 & 452.4 & 0.1 & 399.4 & & & & & \\
\hline CL 70:3 & $\mathrm{C}_{79} \mathrm{H}_{148} \mathrm{O}_{17} \mathrm{P}_{2}$ & {$[\mathrm{M}+\mathrm{H}]+$} & 1432.026 & 454.7 & 0.1 & 401.2 & & & & & \\
\hline
\end{tabular}


Table $\mathrm{S3}^{\mathrm{TW}} \mathrm{CCS}_{\mathrm{N} 2}$ values calibrated with polyalanine for the membrane lipids of PAK

\begin{tabular}{|c|c|c|c|c|c|c|c|c|c|c|c|}
\hline \multirow[b]{2}{*}{$\begin{array}{l}\text { membrane } \\
\text { lipids of } \\
\text { PAK }\end{array}$} & \multirow[b]{2}{*}{ Formula } & \multicolumn{5}{|c|}{ Positive ions } & \multicolumn{5}{|c|}{ Negative ions } \\
\hline & & ion & $m / z$ & $\begin{array}{l}{ }^{\mathrm{TW}} \mathrm{CCS}_{\mathrm{N} 2} \\
\text { without } \\
\text { correction }\end{array}$ & $\begin{array}{l}{ }^{\mathrm{TW}} \mathrm{CCS}_{\mathrm{N2}} \\
\text { \%RSD }\end{array}$ & $\begin{array}{c}\text { corrected } \\
{ }^{\mathrm{TW}} \operatorname{CCS}_{\mathrm{N} 2}\left(\AA^{2}\right)\end{array}$ & ion & $m / z$ & $\begin{array}{l}{ }^{\mathrm{TW}} \mathrm{CCS}_{\mathrm{N} 2} \\
\text { without } \\
\text { correction }\end{array}$ & $\begin{array}{l}{ }^{\mathrm{TW}} \mathrm{CCS}_{\mathrm{N} 2} \\
\text { \%RSD }\end{array}$ & $\begin{array}{c}\text { corrected } \\
{ }^{\mathrm{TW}}{ }^{2} \mathrm{CCS}_{\mathrm{N} 2} \\
\left(\AA^{2}\right)\end{array}$ \\
\hline PC 32:1 & $\mathrm{C}_{40} \mathrm{H}_{78} \mathrm{NO}_{8} \mathrm{P}$ & {$[\mathrm{M}+\mathrm{H}]^{+}$} & 732.5538 & 291.9 & 0.1 & 278.9 & & & & & \\
\hline PC 32:0 & $\mathrm{C}_{40} \mathrm{H}_{80} \mathrm{NO}_{8} \mathrm{P}$ & {$[\mathrm{M}+\mathrm{H}]^{+}$} & 734.5694 & 295.5 & 0.1 & 282.1 & & & & & \\
\hline PC 34:2 & $\mathrm{C}_{42} \mathrm{H}_{82} \mathrm{NO}_{8} \mathrm{P}$ & {$[\mathrm{M}+\mathrm{H}]^{+}$} & 758.5694 & 295.4 & 0.1 & 282.0 & & & & & \\
\hline PC 34:1 & $\mathrm{C}_{42} \mathrm{H}_{82} \mathrm{NO}_{8} \mathrm{P}$ & {$[\mathrm{M}+\mathrm{H}]^{+}$} & 760.5851 & 298.6 & 0.1 & 284.8 & & & & & \\
\hline PC 34:0 & $\mathrm{C}_{42} \mathrm{H}_{84} \mathrm{NO}_{8} \mathrm{P}$ & {$[\mathrm{M}+\mathrm{H}]^{+}$} & 762.6007 & 301.6 & 0.4 & 287.4 & & & & & \\
\hline PC 35:1 & $\mathrm{C}_{43} \mathrm{H}_{84} \mathrm{NO}_{8} \mathrm{P}$ & {$[\mathrm{M}+\mathrm{H}]+$} & 774.6007 & 303.5 & 0.1 & 289.1 & & & & & \\
\hline PC 36:2 & $\mathrm{C}_{42} \mathrm{H}_{82} \mathrm{NO}_{8} \mathrm{P}$ & {$[\mathrm{M}+\mathrm{H}]^{+}$} & 786.6007 & 302.4 & 0.1 & 288.2 & & & & & \\
\hline PE 30:1 & $\mathrm{C}_{35} \mathrm{H}_{68} \mathrm{NO}_{8} \mathrm{P}$ & {$[\mathrm{M}+\mathrm{H}]^{+}$} & 662.4755 & 270.9 & 0.1 & 260.4 & {$[\mathrm{M}-\mathrm{H}]^{-}$} & 660.4610 & 259.2 & 0.1 & 249.7 \\
\hline PE 30:0 & $\mathrm{C}_{35} \mathrm{H}_{70} \mathrm{NO}_{8} \mathrm{P}$ & & & & & & {$[\mathrm{M}-\mathrm{H}]^{-}$} & 662.4766 & 261.6 & 0.1 & 251.8 \\
\hline PE 32:2 & $\mathrm{C}_{37} \mathrm{H}_{70} \mathrm{NO}_{8} \mathrm{P}$ & {$[\mathrm{M}+\mathrm{H}]^{+}$} & 688.4912 & 273.1 & 0.1 & 262.4 & {$[\mathrm{M}-\mathrm{H}]^{-}$} & 686.4766 & 263.8 & 0.2 & 253.7 \\
\hline PE 32:1 & $\mathrm{C}_{37} \mathrm{H}_{72} \mathrm{NO}_{8} \mathrm{P}$ & {$[\mathrm{M}+\mathrm{H}]^{+}$} & 690.5068 & 277.8 & 0.1 & 266.5 & {$[\mathrm{M}-\mathrm{H}]^{-}$} & 688.4923 & 265.7 & 0.1 & 255.4 \\
\hline PE 32:0 & $\mathrm{C}_{37} \mathrm{H}_{74} \mathrm{NO}_{8} \mathrm{P}$ & {$[\mathrm{M}+\mathrm{H}]^{+}$} & 692.5225 & 283.6 & 0.0 & 271.6 & {$[\mathrm{M}-\mathrm{H}]^{-}$} & 690.5079 & 267.6 & 0.1 & 257.1 \\
\hline PE 33:1 & $\mathrm{C}_{38} \mathrm{H}_{74} \mathrm{NO}_{8} \mathrm{P}$ & {$[\mathrm{M}+\mathrm{H}]^{+}$} & 704.5225 & 283.2 & 0.1 & 271.2 & {$[\mathrm{M}-\mathrm{H}]^{-}$} & 702.5079 & 269.5 & 0.1 & 258.8 \\
\hline PE 34:2 & $\mathrm{C}_{39} \mathrm{H}_{73} \mathrm{NO}_{8} \mathrm{P}$ & {$[\mathrm{M}+\mathrm{H}]^{+}$} & 716.5225 & 280.6 & 0.1 & 269.0 & {$[\mathrm{M}-\mathrm{H}]^{-}$} & 714.5079 & 270.9 & 0.1 & 260.0 \\
\hline PE 34:1 & $\mathrm{C}_{37} \mathrm{H}_{76} \mathrm{NO}_{8} \mathrm{P}$ & {$[\mathrm{M}+\mathrm{H}]^{+}$} & 718.5381 & 285.9 & 0.1 & 273.6 & {$[\mathrm{M}-\mathrm{H}]^{-}$} & 716.5236 & 272.8 & 0.0 & 261.7 \\
\hline PE 34:0 & $\mathrm{C}_{39} \mathrm{H}_{78} \mathrm{NO}_{8} \mathrm{P}$ & {$[\mathrm{M}+\mathrm{H}]^{+}$} & 720.5538 & 289.5 & 0.1 & 276.8 & {$[\mathrm{M}-\mathrm{H}]^{-}$} & 718.5392 & 274.8 & 0.1 & 263.4 \\
\hline PE 35:2 & $\mathrm{C}_{40} \mathrm{H}_{76} \mathrm{NO}_{8} \mathrm{P}$ & {$[\mathrm{M}+\mathrm{H}]^{+}$} & 730.5381 & 286.5 & 0.1 & 274.2 & {$[\mathrm{M}-\mathrm{H}]^{-}$} & 728.5236 & 274.2 & 0.1 & 262.9 \\
\hline PE 35:1 & $\mathrm{C}_{40} \mathrm{H}_{78} \mathrm{NO}_{8} \mathrm{P}$ & {$[\mathrm{M}+\mathrm{H}]+$} & 732.5538 & 288.8 & 0.1 & 276.2 & [M-H]- & 730.5392 & 276.6 & 0.0 & 265.0 \\
\hline PE 36:2 & $\mathrm{C}_{41} \mathrm{H}_{78} \mathrm{NO}_{8} \mathrm{P}$ & {$[\mathrm{M}+\mathrm{H}]^{+}$} & 744.5538 & 287.4 & 0.1 & 274.9 & {$[\mathrm{M}-\mathrm{H}]^{-}$} & 742.5392 & 278.0 & 0.2 & 266.3 \\
\hline PE 36:1 & $\mathrm{C}_{41} \mathrm{H}_{80} \mathrm{NO}_{8} \mathrm{P}$ & {$[\mathrm{M}+\mathrm{H}]+$} & 746.5694 & 292.5 & 0.1 & 279.5 & [M-H]- & 744.5549 & 279.9 & 0.1 & 267.9 \\
\hline
\end{tabular}




\begin{tabular}{|c|c|c|c|c|c|c|c|c|c|c|c|}
\hline & & & & & & & \\
\hline $\begin{array}{l}\text { membrane } \\
\text { lipids of PAK }\end{array}$ & Formula & ion & $m / z$ & $\begin{array}{c}\text { Positive ions } \\
{ }^{\mathrm{TW}} \mathrm{CCS}_{\mathrm{N} 2} \\
\text { without } \\
\text { correction }\end{array}$ & $\begin{array}{l}{ }^{\mathrm{TW}} \mathrm{CCS}_{\mathrm{N} 2} \\
\text { \%RSD }\end{array}$ & $\begin{array}{c}\text { corrected } \\
{ }_{\mathrm{Tw}}{ }^{\mathrm{T}} \mathrm{CCS} \mathrm{S}_{\mathrm{N} 2} \\
\left(\AA^{2}\right)\end{array}$ & ion & $m / z$ & $\begin{array}{c}\text { Negative ions } \\
{ }^{\mathrm{TW}} \mathrm{CCS}_{\mathrm{N} 2} \\
\text { without } \\
\text { correction }\end{array}$ & $\begin{array}{l}{ }^{\mathrm{TW}} \mathrm{CCS}_{\mathrm{N} 2} \\
\text { \%RSD }\end{array}$ & $\begin{array}{c}\text { corrected } \\
{ }^{\mathrm{T}}{ }^{\mathrm{C}} \mathrm{CCS}_{\mathrm{N} 2} \\
\left(\AA^{2}\right)\end{array}$ \\
\hline PG 30:0 & $\mathrm{C}_{36} \mathrm{H}_{71} \mathrm{O}_{10} \mathrm{P}$ & & & & & & {$[\mathrm{M}-\mathrm{H}]-$} & 693.4712 & 269.0 & 0.1 & 258.3 \\
\hline PG 32:1 & $\mathrm{C}_{38} \mathrm{H}_{71} \mathrm{O}_{10} \mathrm{P}$ & & & & & & {$[\mathrm{M}-\mathrm{H}]^{-}$} & 719.4869 & 274.8 & 0.1 & 263.4 \\
\hline PG 33:1 & $\mathrm{C}_{39} \mathrm{H}_{75} \mathrm{O}_{10} \mathrm{P}$ & & & & & & {$[\mathrm{M}-\mathrm{H}]^{-}$} & 733.5025 & 276.9 & 0.1 & 265.3 \\
\hline PG 34:2 & $\mathrm{C}_{40} \mathrm{H}_{75} \mathrm{O}_{10} \mathrm{P}$ & & & & & & {$[\mathrm{M}-\mathrm{H}]^{-}$} & 745.5025 & 278.5 & 0.1 & 266.7 \\
\hline PG 34:1 & $\mathrm{C}_{40} \mathrm{H}_{77} \mathrm{O}_{10} \mathrm{P}$ & & & & & & {$[\mathrm{M}-\mathrm{H}]^{-}$} & 747.5182 & 280.6 & 0.1 & 268.6 \\
\hline PG 35:2 & $\mathrm{C}_{40} \mathrm{H}_{75} \mathrm{O}_{10} \mathrm{P}$ & & & & & & {$[\mathrm{M}-\mathrm{H}]^{-}$} & 759.5182 & 282.0 & 0.1 & 269.8 \\
\hline PG 35:1 & $\mathrm{C}_{40} \mathrm{H}_{77} \mathrm{O}_{10} \mathrm{P}$ & & & & & & {$[\mathrm{M}-\mathrm{H}]^{-}$} & 761.5338 & 283.8 & 0.1 & 271.4 \\
\hline PG 36:2 & $\mathrm{C}_{42} \mathrm{H}_{79} \mathrm{O}_{10} \mathrm{P}$ & & & & & & {$[\mathrm{M}-\mathrm{H}]^{-}$} & 773.5338 & 285.3 & 0.1 & 272.7 \\
\hline CL 66:3 & $\mathrm{C}_{75} \mathrm{H}_{140} \mathrm{O}_{17} \mathrm{P}_{2}$ & {$[\mathrm{M}+\mathrm{H}]^{+}$} & 1375.9639 & 416.5 & 0.2 & 388.9 & {$[\mathrm{M}-\mathrm{H}]^{-}$} & 1373.9493 & 409.5 & 0.3 & 382.4 \\
\hline CL 66:2 & $\mathrm{C}_{75} \mathrm{H}_{142} \mathrm{O}_{17} \mathrm{P}_{2}$ & {$[\mathrm{M}+\mathrm{H}]^{+}$} & 1377.9795 & 417.7 & 0.0 & 389.9 & {$[\mathrm{M}-\mathrm{H}]^{-}$} & 1375.9650 & 410.9 & 0.4 & 383.6 \\
\hline CL 66:1 & $\mathrm{C}_{75} \mathrm{H}_{144} \mathrm{O}_{17} \mathrm{P}_{2}$ & {$[\mathrm{M}+\mathrm{H}]^{+}$} & 1379.9952 & 418.6 & 0.1 & 390.6 & & & & & \\
\hline CL 67:3 & $\mathrm{C}_{76} \mathrm{H}_{142} \mathrm{O}_{17} \mathrm{P}_{2}$ & {$[\mathrm{M}+\mathrm{H}]^{+}$} & 1389.9795 & 419.6 & 0.2 & 391.5 & & & & & \\
\hline CL 67:2 & $\mathrm{C}_{76} \mathrm{H}_{144} \mathrm{O}_{17} \mathrm{P}_{2}$ & {$[\mathrm{M}+\mathrm{H}]^{+}$} & 1391.9952 & 420.6 & 0.1 & 392.4 & & & & & \\
\hline CL 68:4 & $\mathrm{C}_{77} \mathrm{H}_{142} \mathrm{O}_{17} \mathrm{P}_{2}$ & {$[\mathrm{M}+\mathrm{H}]^{+}$} & 1401.9795 & 420.9 & 0.2 & 392.7 & & & & & \\
\hline CL 68:3 & $\mathrm{C}_{77} \mathrm{H}_{144} \mathrm{O}_{17} \mathrm{P}_{2}$ & {$[\mathrm{M}+\mathrm{H}]^{+}$} & 1403.9952 & 422.8 & 0.1 & 394.4 & & & & & \\
\hline CL 68:2 & $\mathrm{C}_{77} \mathrm{H}_{146} \mathrm{O}_{17} \mathrm{P}_{2}$ & {$[\mathrm{M}+\mathrm{H}]^{+}$} & 1406.0108 & 424.7 & 0.2 & 396.1 & {$[\mathrm{M}-\mathrm{H}]^{-}$} & 1403.9963 & 417.0 & 0.3 & 389.1 \\
\hline CL 69:4 & $\mathrm{C}_{78} \mathrm{H}_{144} \mathrm{O}_{17} \mathrm{P}_{2}$ & {$[\mathrm{M}+\mathrm{H}]+$} & 1415.9952 & 423.9 & 0.2 & 395.4 & & & & & \\
\hline CL 69:3 & $\mathrm{C}_{78} \mathrm{H}_{146} \mathrm{O}_{17} \mathrm{P}_{2}$ & {$[\mathrm{M}+\mathrm{H}]^{+}$} & 1418.0108 & 425.6 & 0.2 & 396.9 & & & & & \\
\hline CL 69:2 & $\mathrm{C}_{78} \mathrm{H}_{148} \mathrm{O}_{17} \mathrm{P}_{2}$ & {$[\mathrm{M}+\mathrm{H}]^{+}$} & 1420.0265 & 426.5 & 0.1 & 397.6 & & & & & \\
\hline CL 70:4 & $\mathrm{C}_{79} \mathrm{H}_{146} \mathrm{O}_{17} \mathrm{P}_{2}$ & {$[\mathrm{M}+\mathrm{H}]+$} & 1430.0108 & 426.8 & 0.1 & 398.0 & & & & & \\
\hline CL 70:3 & $\mathrm{C}_{79} \mathrm{H}_{148} \mathrm{O}_{17} \mathrm{P}_{2}$ & {$[\mathrm{M}+\mathrm{H}]+$} & 1432.0265 & 428.8 & 0.1 & 399.7 & & & & & \\
\hline
\end{tabular}


Table S4 ${ }^{\mathrm{TW}} \mathrm{CCS}_{\mathrm{N} 2}$ values calibrated with phospholipids for the membrane lipids of PAK

\begin{tabular}{|c|c|c|c|c|c|c|c|c|c|}
\hline \multirow[b]{2}{*}{$\begin{array}{c}\text { membrane lipids } \\
\text { of PAK }\end{array}$} & \multirow[b]{2}{*}{ Formula } & \multicolumn{4}{|c|}{ Positive ions } & \multicolumn{4}{|c|}{ Negative ions } \\
\hline & & ion & $m / z$ & $\begin{array}{c}{ }^{\mathrm{TW}} \mathrm{CCS}_{\mathrm{N} 2} \text { without } \\
\text { correction }\left(\AA^{2}\right)\end{array}$ & ${ }^{\mathrm{TW}} \mathrm{CCS}_{\mathrm{N} 2} \% \mathrm{RSD}$ & ion & $m / z$ & \begin{tabular}{|c|}
${ }^{\mathrm{TW}} \mathrm{CCS}_{\mathrm{N} 2}$ \\
without \\
correction \\
\end{tabular} & ${ }^{\mathrm{TW}} \mathrm{CCS}_{\mathrm{N} 2} \% \mathrm{RSD}$ \\
\hline PC 32:1 & $\mathrm{C}_{40} \mathrm{H}_{78} \mathrm{NO}_{8} \mathrm{P}$ & {$[\mathrm{M}+\mathrm{H}]^{+}$} & 732.5538 & 279.0 & 0.1 & & & & \\
\hline PC 32:0 & $\mathrm{C}_{40} \mathrm{H}_{80} \mathrm{NO}_{8} \mathrm{P}$ & {$[\mathrm{M}+\mathrm{H}]^{+}$} & 734.5694 & 282.2 & 0.1 & & & & \\
\hline PC 34:2 & $\mathrm{C}_{42} \mathrm{H}_{82} \mathrm{NO}_{8} \mathrm{P}$ & {$[\mathrm{M}+\mathrm{H}]^{+}$} & 758.5694 & 282.1 & 0.1 & & & & \\
\hline PC 34:1 & $\mathrm{C}_{42} \mathrm{H}_{82} \mathrm{NO}_{8} \mathrm{P}$ & {$[\mathrm{M}+\mathrm{H}]^{+}$} & 760.5851 & 284.9 & 0.1 & & & & \\
\hline PC 34:0 & $\mathrm{C}_{42} \mathrm{H}_{84} \mathrm{NO}_{8} \mathrm{P}$ & {$[\mathrm{M}+\mathrm{H}]^{+}$} & 762.6007 & 287.4 & 0.3 & & & & \\
\hline PC 35:1 & $\mathrm{C}_{43} \mathrm{H}_{84} \mathrm{NO}_{8} \mathrm{P}$ & {$[\mathrm{M}+\mathrm{H}]+$} & 774.6007 & 289.1 & 0.1 & & & & \\
\hline PC 36:2 & $\mathrm{C}_{42} \mathrm{H}_{82} \mathrm{NO}_{8} \mathrm{P}$ & {$[\mathrm{M}+\mathrm{H}]^{+}$} & 786.6007 & 288.2 & 0.1 & & & & \\
\hline PE 30:1 & $\mathrm{C}_{35} \mathrm{H}_{68} \mathrm{NO}_{8} \mathrm{P}$ & {$[\mathrm{M}+\mathrm{H}]^{+}$} & 662.4755 & 260.8 & 0.1 & {$[\mathrm{M}-\mathrm{H}]^{-}$} & 660.4610 & 253.9 & 0.1 \\
\hline PE 30:0 & $\mathrm{C}_{35} \mathrm{H}_{70} \mathrm{NO}_{8} \mathrm{P}$ & & & & & {$[\mathrm{M}-\mathrm{H}]^{-}$} & 662.4766 & 256.0 & 0.1 \\
\hline PE 32:2 & $\mathrm{C}_{37} \mathrm{H}_{70} \mathrm{NO}_{8} \mathrm{P}$ & {$[\mathrm{M}+\mathrm{H}]^{+}$} & 688.4912 & 262.7 & 0.1 & {$[\mathrm{M}-\mathrm{H}]^{-}$} & 686.4766 & 257.9 & 0.2 \\
\hline PE 32:1 & $\mathrm{C}_{37} \mathrm{H}_{72} \mathrm{NO}_{8} \mathrm{P}$ & {$[\mathrm{M}+\mathrm{H}]^{+}$} & 690.5068 & 266.8 & 0.1 & {$[\mathrm{M}-\mathrm{H}]^{-}$} & 688.4923 & 259.5 & 0.1 \\
\hline PE 32:0 & $\mathrm{C}_{37} \mathrm{H}_{74} \mathrm{NO}_{8} \mathrm{P}$ & {$[\mathrm{M}+\mathrm{H}]^{+}$} & 692.5225 & 271.8 & 0.0 & {$[\mathrm{M}-\mathrm{H}]^{-}$} & 690.5079 & 261.2 & 0.1 \\
\hline PE 33:1 & $\mathrm{C}_{38} \mathrm{H}_{74} \mathrm{NO}_{8} \mathrm{P}$ & {$[\mathrm{M}+\mathrm{H}]^{+}$} & 704.5225 & 271.5 & 0.1 & {$[\mathrm{M}-\mathrm{H}]^{-}$} & 702.5079 & 262.9 & 0.1 \\
\hline PE 34:2 & $\mathrm{C}_{39} \mathrm{H}_{73} \mathrm{NO}_{8} \mathrm{P}$ & {$[\mathrm{M}+\mathrm{H}]^{+}$} & 716.5225 & 269.2 & 0.1 & {$[\mathrm{M}-\mathrm{H}]^{-}$} & 714.5079 & 264.1 & 0.1 \\
\hline PE 34:1 & $\mathrm{C}_{37} \mathrm{H}_{76} \mathrm{NO}_{8} \mathrm{P}$ & {$[\mathrm{M}+\mathrm{H}]^{+}$} & 718.5381 & 273.8 & 0.1 & {$[\mathrm{M}-\mathrm{H}]^{-}$} & 716.5236 & 265.7 & 0.0 \\
\hline PE 34:0 & $\mathrm{C}_{39} \mathrm{H}_{78} \mathrm{NO}_{8} \mathrm{P}$ & {$[\mathrm{M}+\mathrm{H}]^{+}$} & 720.5538 & 277.0 & 0.1 & {$[\mathrm{M}-\mathrm{H}]^{-}$} & 718.5392 & 267.4 & 0.1 \\
\hline PE 35:2 & $\mathrm{C}_{40} \mathrm{H}_{76} \mathrm{NO}_{8} \mathrm{P}$ & {$[\mathrm{M}+\mathrm{H}]^{+}$} & 730.5381 & 274.4 & 0.1 & {$[\mathrm{M}-\mathrm{H}]^{-}$} & 728.5236 & 266.9 & 0.1 \\
\hline PE 35:1 & $\mathrm{C}_{40} \mathrm{H}_{78} \mathrm{NO}_{8} \mathrm{P}$ & {$[\mathrm{M}+\mathrm{H}]+$} & 732.5538 & 276.4 & 0.1 & {$[\mathrm{M}-\mathrm{H}]-$} & 730.5392 & 269.0 & 0.0 \\
\hline PE 36:2 & $\mathrm{C}_{41} \mathrm{H}_{78} \mathrm{NO}_{8} \mathrm{P}$ & {$[\mathrm{M}+\mathrm{H}]^{+}$} & 744.5538 & 275.1 & 0.1 & {$[\mathrm{M}-\mathrm{H}]^{-}$} & 742.5392 & 270.2 & 0.1 \\
\hline PE 36:1 & $\mathrm{C}_{41} \mathrm{H}_{80} \mathrm{NO}_{8} \mathrm{P}$ & {$[\mathrm{M}+\mathrm{H}]+$} & 746.5694 & 279.6 & 0.1 & [M-H]- & 744.5549 & 271.8 & 0.1 \\
\hline
\end{tabular}




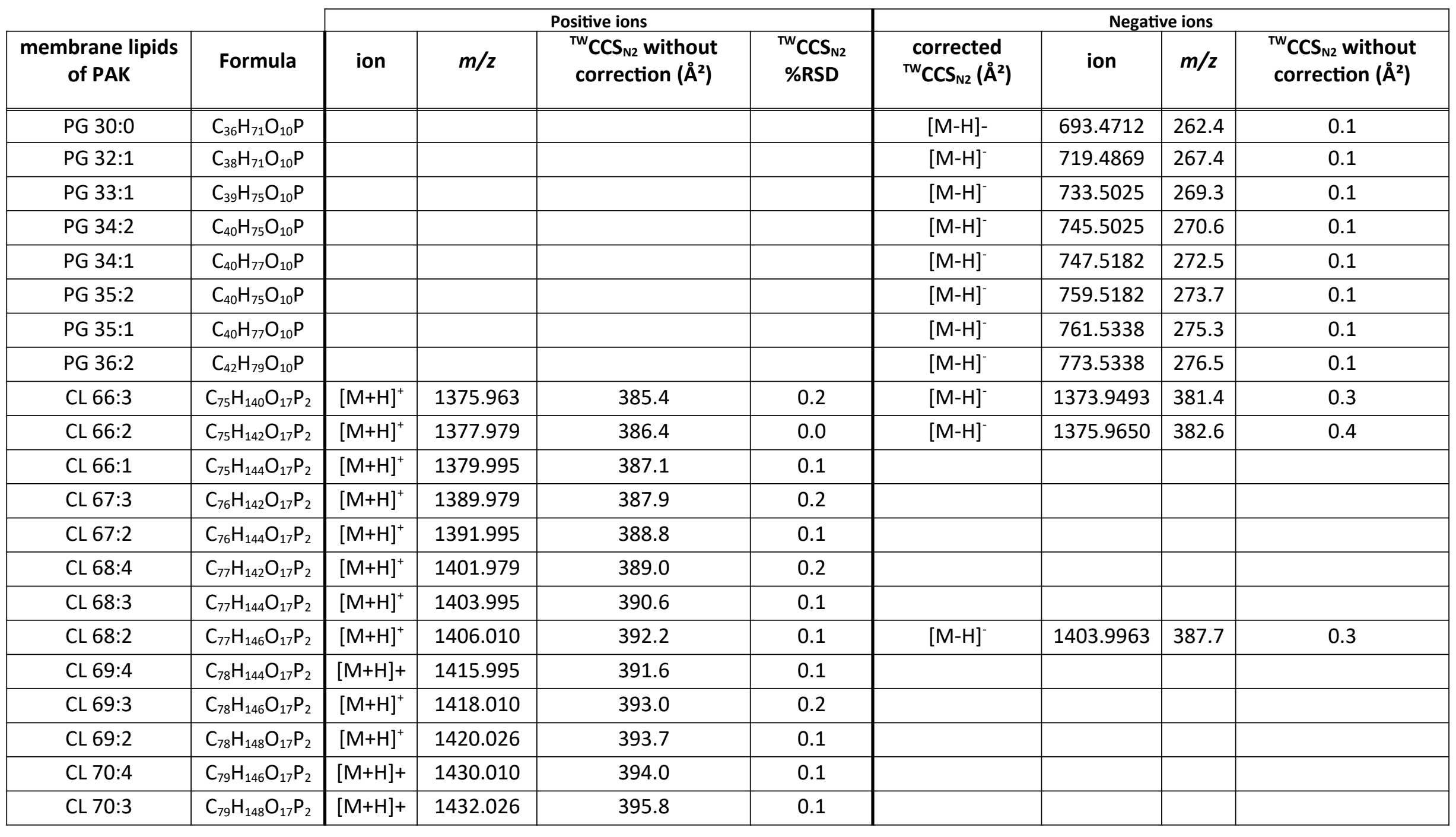


Table S5 Comparison between the experimental ${ }^{\mathrm{TW}} \mathrm{CCS}_{\mathrm{N} 2}$ values for the phospholipids of PAK and CCS values of the literature for $[\mathrm{M}+\mathrm{H}]^{+}$. 1: dextran calibration, 2: dextran calibration and lipid correction, 3: polyalanine calibration, 4: polyalanine calibration and lipid correction, 5 phospholipids calibration

\begin{tabular}{|c|c|c|c|c|c|c|c|c|c|c|c|c|c|c|c|c|c|c|c|c|c|c|c|c|}
\hline \multirow[b]{2}{*}{ Lipid } & \multicolumn{6}{|c|}{ Leaptrot 2019 - drift tube } & \multicolumn{6}{|c|}{ Zhou 2017 - drift tube } & \multicolumn{6}{|c|}{ Hines 2016 - drift tube } & \multicolumn{6}{|c|}{$\begin{array}{c}\text { Paglia } 2015 \text { - TWIMS polyalanine } \\
\text { calibration }\end{array}$} \\
\hline & $\begin{array}{c}\mathrm{CCS} \\
{[\mathrm{M}+\mathrm{H}]+} \\
\left(\AA^{2}\right)\end{array}$ & $\begin{array}{c}\% \Delta \\
1\end{array}$ & $\begin{array}{c}\% \Delta \\
2\end{array}$ & $\begin{array}{c}\% \\
\Delta 3\end{array}$ & $\begin{array}{c}\% \Delta \\
4\end{array}$ & $\begin{array}{c}\% \Delta \\
5\end{array}$ & $\begin{array}{c}\mathrm{CCS} \\
{[\mathrm{M}+\mathrm{H}]+} \\
\left(\AA^{2}\right)\end{array}$ & $\begin{array}{c}\% \\
\Delta 1\end{array}$ & $\begin{array}{c}\% \Delta \\
2\end{array}$ & $\% \Delta 3$ & $\begin{array}{c}\% \Delta \\
4\end{array}$ & $\begin{array}{c}\% \Delta \\
5\end{array}$ & $\begin{array}{c}\mathrm{CCS} \\
{[\mathrm{M}+\mathrm{H}]+} \\
\left(\AA^{2}\right)\end{array}$ & $\begin{array}{c}\% \\
\Delta 1\end{array}$ & $\begin{array}{c}\% \Delta \\
2\end{array}$ & $\begin{array}{c}\% \\
\Delta 3\end{array}$ & $\begin{array}{c}\% \Delta \\
4\end{array}$ & $\begin{array}{c}\% \Delta \\
5\end{array}$ & $\begin{array}{c}\text { CCS } \\
{[\mathrm{M}+\mathrm{H}]+} \\
\left(\AA^{2}\right)\end{array}$ & $\begin{array}{c}\% \\
\Delta 1\end{array}$ & $\begin{array}{c}\% \Delta \\
2\end{array}$ & $\begin{array}{c}\% \Delta \\
3\end{array}$ & $\begin{array}{c}\% \Delta \\
4\end{array}$ & $\begin{array}{c}\% \Delta \\
5\end{array}$ \\
\hline PC 32:0 & 278.4 & 10.5 & 1.3 & 6.0 & 1.3 & 1.4 & 283.4 & 8.5 & -0.5 & 4.1 & -0.5 & -0.4 & 282.5 & 8.9 & -0.2 & 4.4 & -0.1 & -0.1 & 291.0 & 5.7 & -3.1 & 1.4 & -3.1 & -3.0 \\
\hline PC 32:1 & 276.5 & 9.8 & 0.8 & 5.6 & 0.9 & 0.9 & 282.6 & 7.4 & -1.4 & 3.3 & -1.3 & -1.3 & & & & & & & 287.0 & 5.8 & -2.9 & 1.7 & -2.8 & -2.8 \\
\hline PC 34:0 & & & & & & & 289.7 & 8.5 & -0.8 & 4.1 & -0.8 & -0.8 & & & & & & & 297.0 & 5.8 & -3.3 & 1.5 & -3.2 & -3.2 \\
\hline PC 34:1 & 282.0 & 10.3 & 1.0 & 5.9 & 1.0 & 1.0 & 287.1 & 8.3 & -0.8 & 4.0 & -0.8 & -0.8 & & & & & & & 295.0 & 5.4 & -3.5 & 1.2 & -3.5 & -3.4 \\
\hline PC $34: 2$ & 279.5 & 10.0 & 0.9 & 5.7 & 1.9 & 1.9 & 285.2 & 7.8 & -1.2 & 3.6 & -0.1 & -0.1 & & & & & & & 293.0 & 4.9 & -3.8 & 0.8 & -2.8 & -2.8 \\
\hline PC 35:1 & 287.1 & 10.2 & 0.7 & 5.7 & 0.7 & 0.7 & 289.2 & 9.4 & -0.1 & 4.9 & 0.0 & 0.0 & & & & & & & & & & & & \\
\hline PC $36: 2$ & 288.6 & 9.2 & -0.2 & 4.8 & -0.1 & -0.1 & 291.3 & 8.2 & -1.1 & 3.8 & -1.1 & -1.1 & & & & & & & 301.0 & 4.7 & -4.3 & 0.5 & -4.3 & -4.3 \\
\hline PE 32:0 & & & & & & & 271.4 & 8.5 & 0.0 & 4.5 & 0.1 & 0.1 & 271.5 & 8.5 & 0.0 & 4.5 & 0.0 & 0.1 & & & & & & \\
\hline PE 32:1 & & & & & & & 267.2 & 7.9 & -0.3 & 4.0 & -0.3 & -0.2 & & & & & & & & & & & & \\
\hline PE 32:2 & & & & & & & & & & & & & 263.8 & 7.4 & -0.6 & 3.5 & -0.5 & -0.4 & & & & & & \\
\hline PE 34:0 & & & & & & & 277.5 & 8.5 & -0.3 & 4.3 & -0.3 & -0.2 & 277.4 & 8.5 & -0.3 & 4.4 & -0.2 & -0.1 & & & & & & \\
\hline PE 34:1 & 270.1 & 10.0 & 1.2 & 5.9 & 1.3 & 1.4 & 274.7 & 8.2 & -0.5 & 4.1 & -0.4 & -0.3 & 273.4 & 8.7 & 0.0 & 4.6 & 0.1 & 0.1 & 272.0 & 9.2 & 0.5 & 5.1 & 0.6 & 0.7 \\
\hline PE 34:2 & 268.5 & 8.5 & 0.1 & 4.5 & 0.2 & 0.3 & 272.7 & 6.8 & -1.4 & 2.9 & -1.4 & -1.3 & & & & & & & & & & & & \\
\hline PE 35:1 & & & & & & & 276.6 & 8.6 & -0.2 & 4.4 & -0.1 & -0.1 & & & & & & & & & & & & \\
\hline PE 35:2 & & & & & & & 275.0 & 8.3 & -0.4 & 4.2 & -0.3 & -0.2 & & & & & & & & & & & & \\
\hline PE 36:1 & 277.0 & 9.9 & 0.8 & 5.6 & 0.9 & 0.9 & 281.3 & 8.2 & -0.7 & 4.0 & -0.7 & -0.6 & & & & & & & & & & & & \\
\hline PE 36:2 & 275.1 & 8.6 & -0.1 & 4.5 & -0.1 & 0.0 & 279.3 & 7.0 & -1.6 & 2.9 & -1.6 & -1.5 & 277.9 & 7.5 & -1.1 & 3.4 & -1.1 & -1.0 & 279.0 & 7.1 & -1.5 & 3.0 & -1.5 & -1.4 \\
\hline
\end{tabular}

Table $\mathbf{5 6}$ Comparison between the experimental ${ }^{\mathrm{TW}} \mathrm{CCS}_{\mathrm{N} 2}$ values for the phospholipids of PAK and CCS values of the literature for [M-H]'. 
1: dextran calibration, 2: dextran calibration and lipid correction, 3: polyalanine calibration, 4: polyalanine calibration and lipid correction, 5 phospholipids calibration

\begin{tabular}{|c|c|c|c|c|c|c|c|c|c|c|c|c|c|c|c|c|c|c|c|c|c|c|c|c|}
\hline \multirow[b]{2}{*}{ Lipid } & \multicolumn{6}{|c|}{ Leaptrot 2019 - drift tube } & \multicolumn{6}{|c|}{ Zhou 2017 - drift tube } & \multicolumn{6}{|c|}{ Hines 2016 - drift tube } & \multicolumn{6}{|c|}{$\begin{array}{l}\text { Paglia } 2015 \text { - TWIMS polyalanine } \\
\text { calibration }\end{array}$} \\
\hline & $\begin{array}{c}\text { CCS } \\
{[\mathrm{M}-\mathrm{H}]^{-}} \\
\left(\AA^{\mathbf{2}}\right) \\
\end{array}$ & $\begin{array}{c}\% \Delta \\
1\end{array}$ & $\begin{array}{c}\% \Delta \\
2\end{array}$ & $\begin{array}{c}\% \Delta \\
3\end{array}$ & $\begin{array}{c}\% \Delta \\
4\end{array}$ & $\begin{array}{c}\% \Delta \\
5\end{array}$ & $\begin{array}{c}\text { CCS } \\
{[\mathrm{M}-\mathrm{H}]^{-}} \\
\left(\AA^{2}\right) \\
\end{array}$ & $\begin{array}{c}\% \Delta \\
1\end{array}$ & $\begin{array}{c}\% \Delta \\
2\end{array}$ & $\begin{array}{c}\% \Delta \\
3\end{array}$ & $\begin{array}{c}\% \Delta \\
4\end{array}$ & $\begin{array}{c}\% \Delta \\
5\end{array}$ & $\begin{array}{c}\text { CCS } \\
{[\mathrm{M}-\mathrm{H}]^{-}} \\
\left(\AA^{2}\right) \\
\end{array}$ & $\begin{array}{c}\% \Delta \\
1\end{array}$ & $\begin{array}{c}\% \Delta \\
2\end{array}$ & $\begin{array}{c}\% \Delta \\
3\end{array}$ & $\begin{array}{c}\% \Delta \\
4\end{array}$ & $\begin{array}{c}\% \Delta \\
5\end{array}$ & $\begin{array}{c}\text { CCS } \\
{[\mathrm{M}-\mathrm{H}]^{-}} \\
\left(\AA^{\mathbf{2}}\right) \\
\end{array}$ & $\begin{array}{c}\% \Delta \\
1\end{array}$ & $\begin{array}{c}\% \Delta \\
2\end{array}$ & $\begin{array}{c}\% \Delta \\
3\end{array}$ & $\begin{array}{c}\% \Delta \\
4\end{array}$ & $\begin{array}{c}\% \Delta \\
5\end{array}$ \\
\hline $\mathrm{PE}(30: 0)$ & & & & & & & & & & & & & 253.3 & 6.0 & -1.4 & 2.3 & -1.4 & 0.2 & & & & & & \\
\hline $\operatorname{PE}(32: 1)$ & & & & & & & 256.6 & 6.2 & -0.5 & 3.5 & -0.5 & 1.1 & & & & & & & & & & & & \\
\hline $\operatorname{PE}(32: 0)$ & & & & & & & & & & & & & 259.4 & 5.8 & -0.9 & 3.2 & -0.9 & 0.7 & & & & & & \\
\hline $\operatorname{PE}(32: 2)$ & & & & & & & & & & & & & 256.3 & 5.6 & -1.0 & 2.9 & -1.0 & 0.6 & & & & & & \\
\hline $\operatorname{PE}(34: 0)$ & & & & & & & & & & & & & 265.5 & 6.0 & -0.8 & 3.5 & -0.8 & 0.7 & 274 & 2.7 & -3.9 & 0.3 & -3.9 & -2.4 \\
\hline $\operatorname{PE}(34: 1)$ & 266.9 & 4.7 & -2.0 & 2.2 & -2.0 & -0.5 & 263.1 & 6.2 & -0.6 & 3.7 & -0.5 & 1.0 & 264.5 & 5.7 & -1.1 & 3.1 & -1.1 & 0.5 & & & & & & \\
\hline $\operatorname{PE}(34: 2)$ & 265.6 & 4.6 & -2.1 & 2.0 & -2.1 & -0.6 & & & & & & & & & & & & & & & & & & \\
\hline $\operatorname{PE}(36: 1)$ & 273.6 & 4.7 & -2.1 & 2.3 & -2.1 & -0.7 & & & & & & & & & & & & & & & & & & \\
\hline $\mathrm{PE}(36: 2)$ & 272.1 & 4.6 & -2.2 & 2.2 & -2.1 & -0.7 & 268.5 & 6.0 & -0.9 & 3.5 & -0.8 & 0.6 & 270.7 & 5.1 & -1.7 & 2.7 & -1.6 & -0.2 & & & & & & \\
\hline $\begin{array}{c}\text { PG(32:1 } \\
)\end{array}$ & & & & & & & 263.3 & 6.9 & 0.0 & 4.4 & 0.0 & 1.6 & & & & & & & & & & & & \\
\hline $\begin{array}{c}\text { PG(33:1 } \\
)\end{array}$ & & & & & & & 266.4 & 6.4 & -0.4 & 4.0 & -0.4 & 1.1 & & & & & & & & & & & & \\
\hline $\begin{array}{c}\text { PG }(34: 0 \\
)\end{array}$ & & & & & & & & & & & & & & & & & & & 283 & 2.0 & -4.7 & -0.3 & -4.6 & -3.3 \\
\hline $\begin{array}{c}\text { PG(34:1 } \\
)\end{array}$ & & & & & & & 270.2 & 6.3 & -0.6 & 3.8 & -0.6 & 0.9 & & & & & & & 281 & 2.2 & -4.4 & -0.1 & -4.4 & -3.0 \\
\hline $\begin{array}{c}\mathrm{PG}(34: 2 \\
)\end{array}$ & & & & & & & 268.7 & 6.1 & -0.8 & 3.6 & -0.7 & 0.7 & & & & & & & 279 & 2.2 & -4.4 & -0.2 & -4.4 & -3.0 \\
\hline $\begin{array}{c}\text { PG(35:1 } \\
)\end{array}$ & & & & & & & 272.7 & 6.4 & -0.5 & 4.1 & -0.5 & 0.9 & & & & & & & & & & & & \\
\hline $\begin{array}{c}\text { PG(36:2 } \\
)\end{array}$ & & & & & & & & & & & & & & & & & & & 289 & 0.9 & -5.7 & -1.3 & -5.6 & -4.3 \\
\hline
\end{tabular}


Table S7: $\triangle \mathrm{CCS}(\%)$ comparison between CCS values of the literature for $[\mathrm{M}+\mathrm{H}]^{+}$

\begin{tabular}{|c|c|c|c|c|c|}
\hline Lipid & $\begin{array}{c}\text { Leaptrot / } \\
\text { Zhou }\end{array}$ & $\begin{array}{c}\text { Leaptrot / } \\
\text { Hines }\end{array}$ & $\begin{array}{c}\text { Zhou / } \\
\text { Hines }\end{array}$ & $\begin{array}{c}\text { Zhou / } \\
\text { Paglia }\end{array}$ & $\begin{array}{c}\text { Hines / } \\
\text { Paglia }\end{array}$ \\
\hline $\mathrm{PC}(32: 0)$ & -1.8 & -1.5 & 0.3 & -2.6 & -2.9 \\
\hline $\mathrm{PC}(32: 1)$ & -2.2 & & & -1.5 & \\
\hline $\mathrm{PC}(34: 0)$ & & & & -2.5 & \\
\hline $\mathrm{PC}(34: 1)$ & -1.8 & & & -2.7 & \\
\hline $\mathrm{PC}(34: 2)$ & -2.0 & & & -2.7 & \\
\hline $\mathrm{PC}(36: 2)$ & -0.9 & & & -3.2 & \\
\hline $\mathrm{PE}(32: 0)$ & & & 0.0 & & \\
\hline $\mathrm{PE}(34: 0)$ & & & 0.0 & & \\
\hline $\mathrm{PE}(34: 1)$ & -1.7 & -1.2 & 0.5 & 1.0 & 0.5 \\
\hline $\mathrm{PE}(36: 2)$ & -1.5 & -1.0 & 0.5 & 0.1 & -0.4 \\
\hline
\end{tabular}

Table S8: $\triangle \mathrm{CCS}(\%)$ comparison between CCS values of the literature for $[\mathrm{M}-\mathrm{H}]$

\begin{tabular}{|c|c|c|c|c|}
\cline { 2 - 5 } \multicolumn{1}{c|}{} & \multicolumn{4}{c|}{$\Delta$ Comparison between the literature (\%) } \\
\hline Lipid & $\begin{array}{c}\text { Leaptrot / } \\
\text { Zhou }\end{array}$ & $\begin{array}{c}\text { Leaptrot / } \\
\text { Hines }\end{array}$ & $\begin{array}{c}\text { Zhou / } \\
\text { Hines }\end{array}$ & $\begin{array}{c}\text { Zhou / } \\
\text { Paglia }\end{array}$ \\
\hline PE(34:1) & 1.4 & 0.9 & -0.5 & \\
\hline PE(36:2) & 1.3 & 0.5 & -0.8 & \\
\hline PG(34:1) & & & & -3.8 \\
\hline PG(34:2) & & & & -3.7 \\
\hline
\end{tabular}


557
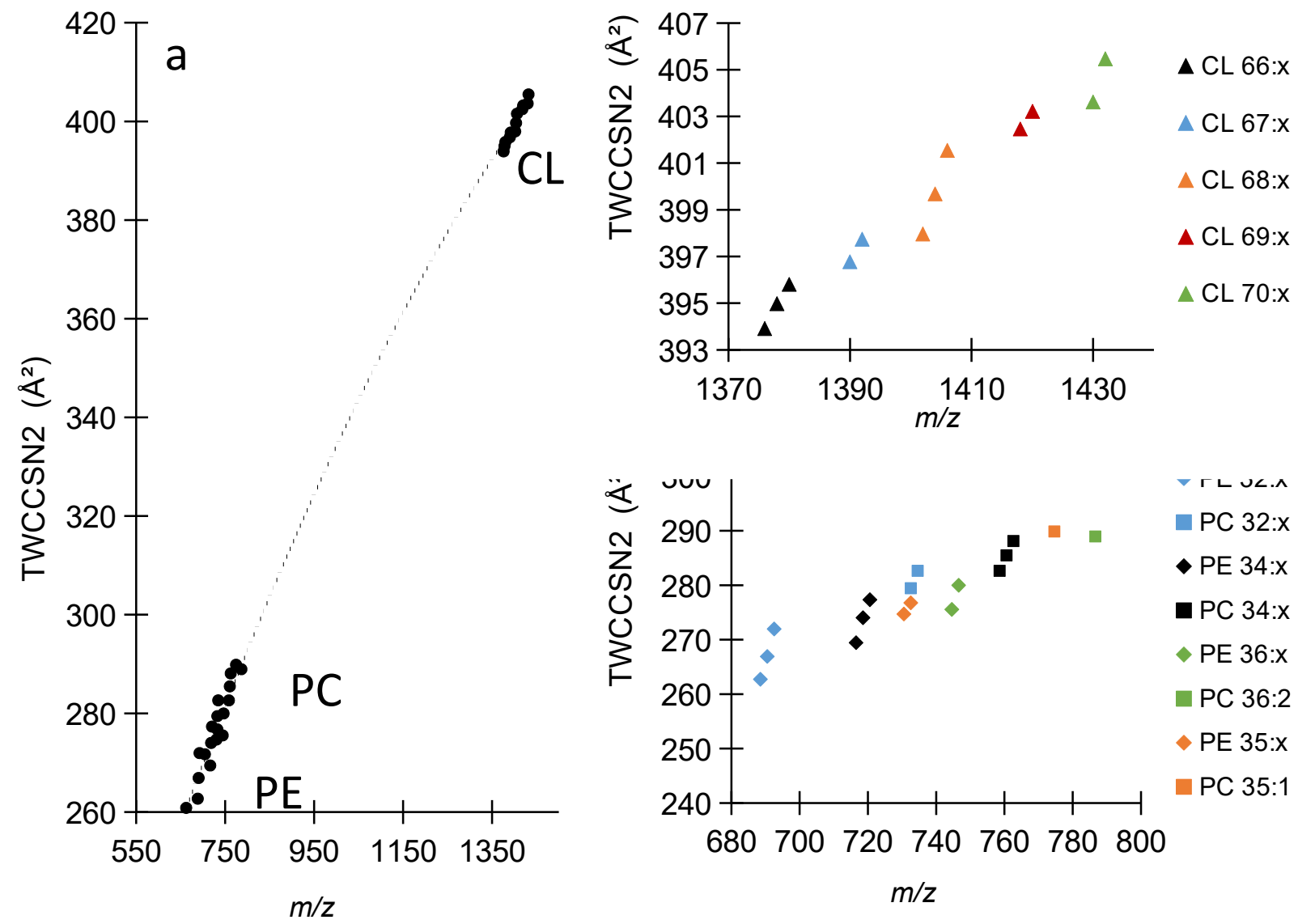

558 Figure S9: ${ }^{\mathrm{TW}} \mathrm{CCS}_{\mathrm{N} 2}$ values plotted against $\mathrm{m} / \mathrm{z}$ for positive ions. (a) represents values for every 559 class of phospholipids, whereas (b) only represents values for CLs and (c) only represents 560 values for PCs and PEs. CLs are represented by triangles, PCs are represented by squares, PEs 561 by diamonds. $x$ refers to the number of double-bonds on the fatty acid moiety of the 562 phospholipid which can be equal to 0, 1, 2 (for PCs and PEs) or up to 3, 4 (for CLs). 
S2 Dextran, polyalanine and phospholipids CCS Calibration

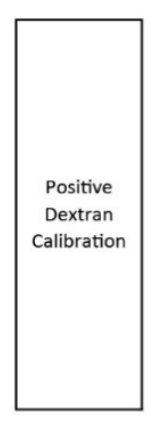

M(N2)

28.0134

\begin{tabular}{|cl|ccc|c|}
\hline $\mathrm{Glc}_{\mathrm{n}}$ & & $\mathrm{m} / \mathrm{z}$ & $\mathrm{z}$ & $\mathrm{m}$ & $\mathrm{CCS}\left(\mathrm{N}_{2}\right)$ in $\AA^{2}$ \\
\hline 2 & {$[\mathrm{M}+\mathrm{Na}]^{+}$} & 365.11 & 1 & 365.11 & 179.54 \\
3 & {$[\mathrm{M}+\mathrm{Na}]^{+}$} & 527.16 & 1 & 527.16 & 215.00 \\
4 & {$[\mathrm{M}+\mathrm{Na}]^{+}$} & 689.21 & 1 & 689.21 & 243.36 \\
5 & {$[\mathrm{M}+\mathrm{Na}]^{+}$} & 851.26 & 1 & 851.26 & 273.81 \\
6 & {$[\mathrm{M}+\mathrm{Na}]^{+}$} & 1013.32 & 1 & 1013.32 & 302.06 \\
7 & {$[\mathrm{M}+\mathrm{Na}]^{+}$} & 1175.37 & 1 & 1175.37 & 330.94 \\
8 & {$[\mathrm{M}+\mathrm{Na}]^{+}$} & 1337.42 & 1 & 1337.42 & 355.80 \\
9 & {$[\mathrm{M}+\mathrm{Na}]^{+}$} & 1499.48 & 1 & 1499.48 & 377.70
\end{tabular}

\begin{tabular}{|c|c|}
\hline $1 / \mu$ & $\Omega^{\prime}(\mathrm{N} 2)$ litt \\
\hline 0.04 & 915.77 \\
0.04 & 1108.88 \\
0.04 & 1262.66 \\
0.04 & 1425.94 \\
0.04 & 1577.08 \\
0.04 & 1731.10 \\
0.04 & 1863.77 \\
0.04 & 1980.68 \\
\hline
\end{tabular}

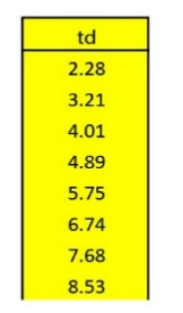

\begin{tabular}{|c|c|}
\hline $\ln \left(\Omega^{\prime}(\mathrm{N} 2)\right)$ & $\ln (\mathrm{td})$ \\
\hline 6.82 & 0.82 \\
7.01 & 1.17 \\
7.14 & 1.39 \\
7.26 & 1.59 \\
7.36 & 1.75 \\
7.46 & 1.91 \\
7.53 & 2.04 \\
7.59 & 2.14 \\
\hline
\end{tabular}
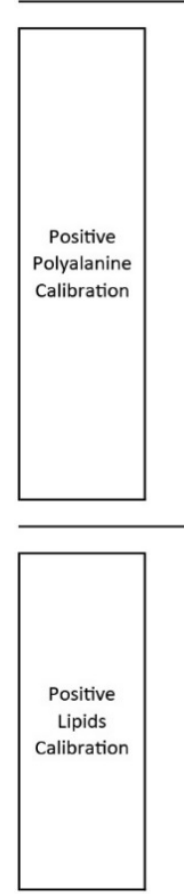

$\mathrm{M}(\mathrm{N} 2)$

28.0134

\begin{tabular}{|l|ccc|c|}
\hline Sequenz & $\mathrm{m} / \mathrm{z}$ & $\mathrm{z}$ & $\mathrm{m}$ & $\mathrm{CCS}\left(\mathrm{N}_{2}\right)$ in $\AA^{2}$ \\
\hline A4 & 303.208 & 1 & 303.2 & 166.00 \\
A5 & 374.208 & 1 & 374.2 & 181.00 \\
A6 & 445.208 & 1 & 445.2 & 195.00 \\
A7 & 516.308 & 1 & 516.3 & 211.00 \\
A8 & 587.308 & 1 & 587.3 & 228.00 \\
A9 & 658.308 & 1 & 658.3 & 243.00 \\
A10 & 729.408 & 1 & 729.4 & 256.00 \\
A11 & 800.408 & 1 & 800.4 & 271.00 \\
A12 & 871.508 & 1 & 871.5 & 282.00 \\
A13 & 942.508 & 1 & 942.5 & 294.00 \\
A14 & 1013.508 & 1 & 1013.5 & 306.00 \\
& & & & \\
\hline
\end{tabular}

\begin{tabular}{|c|c|}
\hline $1 / \mu$ & $\Omega^{\prime}(\mathrm{N} 2)$ litt \\
\hline 0.04 & 840.62 \\
0.04 & 924.03 \\
0.04 & 1001.08 \\
0.04 & 1087.66 \\
0.04 & 1178.96 \\
0.04 & 1259.62 \\
0.04 & 1329.66 \\
0.04 & 1409.88 \\
0.04 & 1469.14 \\
0.04 & 1533.45 \\
0.04 & 1597.66 \\
\hline
\end{tabular}

\begin{tabular}{|c|}
\hline $\mathrm{td}$ \\
\hline 2.06 \\
2.42 \\
2.76 \\
3.17 \\
3.67 \\
4.12 \\
4.54 \\
5.01 \\
5.50 \\
5.98 \\
6.45 \\
\hline
\end{tabular}

\begin{tabular}{|c|c|}
\hline $\ln \left(\Omega^{\prime}(\mathrm{N} 2)\right)$ & $\ln (\mathrm{td})$ \\
\hline 6.73 & 0.72 \\
6.83 & 0.88 \\
6.91 & 1.02 \\
6.99 & 1.15 \\
7.07 & 1.30 \\
7.14 & 1.42 \\
7.19 & 1.51 \\
7.25 & 1.61 \\
7.29 & 1.70 \\
7.34 & 1.79 \\
7.38 & 1.86
\end{tabular}




\begin{tabular}{|c|c|c|c|c|c|c|c|c|c|c|c|c|c|}
\hline \multirow{10}{*}{$\begin{array}{c}\text { Negative } \\
\text { Dextran } \\
\text { Calibration }\end{array}$} & \multicolumn{8}{|c|}{28.0134} & \multirow[b]{2}{*}{$\mathrm{td}$} & \multirow[b]{2}{*}{$\ln \left(\Omega^{\prime}\left(\mathrm{N}_{2}\right)\right)$} & \multirow[b]{2}{*}{$\ln (\mathrm{td})$} & & \\
\hline & $G c_{n}$ & & $\mathrm{~m} / \mathrm{z}$ & $z$ & $\mathrm{~m}$ & $\operatorname{CCS}\left(\mathrm{N}_{2}\right)$ in $A^{2}$ & $1 / \mu$ & $\Omega^{\prime}(\mathrm{N} 2)$ litt & & & & & \\
\hline & 2 & {$[\mathrm{M}-\mathrm{H}]^{-}$} & 341.11 & 1 & 341.11 & 174.56 & 0.04 & 888.17 & 2.02 & 6.79 & 0.70 & & \\
\hline & 3 & {$[\mathrm{M}-\mathrm{H}]^{-}$} & 503.16 & 1 & 503.16 & 202.34 & 0.04 & 1042.30 & 3.03 & 6.95 & 1.11 & & \\
\hline & 4 & {$[\mathrm{M}-\mathrm{H}]^{-}$} & 665.21 & 1 & 665.21 & 233.96 & 0.04 & 1213.00 & 3.92 & 7.10 & 1.37 & & \\
\hline & 5 & {$[M-H]^{-}$} & 827.27 & 1 & 827.27 & 265.39 & 0.04 & 1381.45 & 4.86 & 7.23 & 1.58 & & \\
\hline & 6 & {$[\mathrm{M}-\mathrm{H}]^{-}$} & 989.32 & 1 & 989.32 & 296.73 & 0.04 & 1548.76 & 5.85 & 7.35 & 1.77 & $\mathrm{x}$ & 0.546 \\
\hline & 7 & {$[M-H]^{3}$} & 1151.37 & 1 & 1151.37 & 319.21 & 0.04 & 1669.34 & 6.71 & 7.42 & 1.90 & $\ln A$ & 6.374 \\
\hline & 8 & {$[\mathrm{M}-\mathrm{H}]^{\top}$} & 1313.43 & 1 & 1313.43 & 343.55 & 0.04 & 1799.25 & 7.71 & 7.50 & 2.04 & A & 586.226 \\
\hline & 9 & {$[\mathrm{M}-\mathrm{H}]^{-}$} & 1475.48 & 1 & 1475.48 & 365.21 & 0.04 & 1914.89 & 8.64 & 7.56 & 2.16 & $r^{2}$ & 0.9953 \\
\hline
\end{tabular}

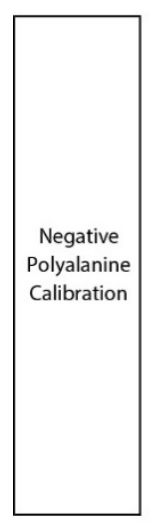

$\mathrm{M}(\mathrm{N} 2)$

28.0134

\begin{tabular}{|c|c|c|c|c|c|c|c|c|c|c|c|}
\hline Sequenz & $\mathrm{m} / \mathrm{z}$ & $z$ & $\mathrm{~m}$ & $\operatorname{CCS}\left(\mathrm{N}_{2}\right)$ in $\AA^{2}$ & $1 / \mu$ & $\Omega^{\prime}(\mathrm{N} 2)$ litt & td & $\left.\ln \left(\Omega^{\prime}\left(N_{2}\right)\right)\right)$ & $\ln (\mathrm{td})$ & & \\
\hline \begin{tabular}{|l|} 
A4 \\
\end{tabular} & 301.151 & 1 & 301.2 & 165.00 & 0.04 & 835.32 & 2.09 & 6.73 & 0.74 & & \\
\hline A5 & 372.188 & 1 & 372.2 & 179.00 & 0.04 & 913.65 & 2.48 & 6.82 & 0.91 & & \\
\hline A6 & 443.225 & 1 & 443.2 & 195.00 & 0.04 & 1000.94 & 2.86 & 6.91 & 1.05 & & \\
\hline A7 & 514.262 & 1 & 514.3 & 209.00 & 0.04 & 1077.24 & 3.28 & 6.98 & 1.19 & $x$ & 0.576 \\
\hline A8 & 585.300 & 1 & 585.3 & 223.00 & 0.04 & 1153.02 & 3.67 & 7.05 & 1.30 & $\operatorname{In} A$ & 6.301 \\
\hline A9 & 656.337 & 1 & 656.3 & 238.00 & 0.04 & 1233.63 & 4.12 & 7.12 & 1.42 & A & 545.101 \\
\hline A10 & 727.374 & 1 & 727.4 & 253.00 & 0.04 & 1314.01 & 4.58 & 7.18 & 1.52 & $r^{2}$ & 0.9998 \\
\hline A11 & 798.411 & 1 & 798.4 & 267.00 & 0.04 & 1389.01 & 5.06 & 7.24 & 1.62 & & \\
\hline A12 & 869.448 & 1 & 869.4 & 279.00 & 0.04 & 1453.45 & 5.50 & 7.28 & 1.70 & & \\
\hline A13 & 940.485 & 1 & 940.5 & 294.00 & 0.04 & 1533.40 & 6.04 & 7.34 & 1.80 & & \\
\hline A14 & 1011.522 & 1 & 1011.5 & 308.00 & 0.04 & 1608.06 & 6.58 & 7.38 & 1.88 & & \\
\hline
\end{tabular}

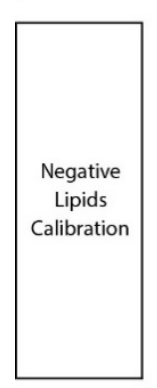

565

\begin{tabular}{|c|c|c|c|c|c|c|}
\hline Lipide & $\mathrm{m} / \mathrm{z}$ & z & $\mathrm{m}$ & $\mathrm{CCS}\left(\mathrm{N}_{2}\right)$ in $\AA^{2}$ & $1 / \mu$ & $\Omega^{\prime}\left(\mathrm{N}_{2}\right)$ litt \\
\hline PEE 6:0/6:0 & 410.1949 & 1 & 410.1949 & 199.3 & 0.04 & 1020.58 \\
\hline PE 10:0/10:0 & 522.3201 & 1 & 522.3201 & 223.2 & 0.04 & 1150.89 \\
\hline PE 15:0/15:0 & 662.4766 & 1 & 662.4766 & 253.3 & 0.04 & 1313.18 \\
\hline PE 17:0/17:0 & 718.5392 & 1 & 718.5392 & 265.5 & 0.04 & 1378.61 \\
\hline PC $20: 0 / 20: 0$ & 904.7012 & 1 & 904.7012 & 305.1 & 0.04 & 1590.39 \\
\hline PC 24:0/24:0 & 1016.8264 & 1 & 1016.8264 & 331 & 0.04 & \\
\hline
\end{tabular}

\begin{tabular}{|c|}
\hline td \\
\hline 3.03 \\
3.85 \\
4.92 \\
5.39 \\
7.15 \\
\hline
\end{tabular}

\begin{tabular}{|c|c|}
\hline $\ln \left(\Omega^{\prime}(\mathrm{N} 2)\right)$ & $\ln (\mathrm{td})$ \\
\hline 6.93 & 1.10 \\
7.05 & 1.34 \\
7.18 & 1.59 \\
7.23 & 1.68 \\
7.37 & 1.96 \\
&
\end{tabular}

$x$
$\ln A$
$A$
$r^{2}$

0.517

0.5179
577.820

$[\mathrm{M}+\mathrm{CH} 3 \mathrm{COO}-]$

\begin{tabular}{ll|l}
$P$ a g e 35 & 37
\end{tabular} 
S3 Dextran and polyalanine correction curves

Positive values

\begin{tabular}{|c|c|c|c|c|c|c|c|c|}
\hline Lipids & $\mathrm{m} / \mathrm{z}$ & $\mathrm{z}$ & $\mathrm{td}$ & $\mathrm{td}$ & $\mathrm{CCS}(\mathrm{N} 2)$ & ${ }^{{ }^{\mathrm{T}}{ }_{\mathrm{CCS}} \mathrm{N}_{2}}$ & ${ }^{\mathrm{DT}} \mathrm{CCS}_{\mathrm{N} 2}$ lit. & $\Omega \% \Delta$ \\
\hline PE 6:0/6:0 & 412.210 & 1 & 2.94 & 2.91 & 1058.4 & 206.7 & 202.1 & 2.3 \\
PE 10:0/10:0 & 524.335 & 1 & 4.06 & 4.02 & 1280.7 & 248.4 & 233.0 & -6.6 \\
PE 15:0/15:0 & 664.491 & 1 & 5.30 & 5.26 & 1498.7 & 289.1 & 265.0 & -9.1 \\
PE 17:0/17:0 & 720.554 & 1 & 5.76 & 5.72 & 1574.0 & 303.1 & 277.4 & -9.3 \\
PC 20:0/20:0 & 846.695 & 1 & 6.96 & 6.91 & 1759.8 & 337.9 & 306.4 & -10.3 \\
PC 24:0/24:0 & 958.820 & 1 & 7.98 & 7.93 & 1907.4 & 365.6 & 330.9 & -10.5
\end{tabular}

correction curve for dextran calibration in positive mode

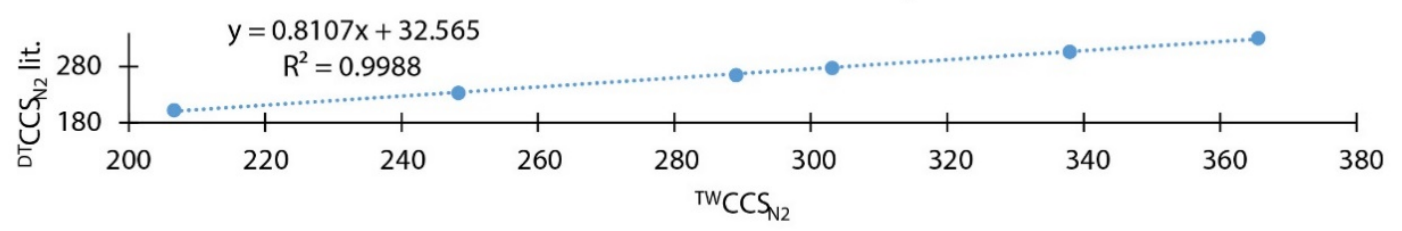

Negative values

\begin{tabular}{|c|c|c|c|c|c|c|c|c|}
\hline Lipids & $\mathrm{m} / \mathrm{z}$ & $\mathrm{z}$ & $\mathrm{td}$ & $\mathrm{td}$ & $\mathrm{CCS}^{\prime}(\mathrm{N} 2)$ & ${ }^{\mathrm{T}}{ } \mathrm{CCS}_{\text {N2 }}$ & ${ }^{\mathrm{DT}} \mathrm{CCS}_{\text {N2 }}$ lit. & $\Omega \% \Delta$ \\
\hline PE 6:0/6:0 & 410.195 & 1 & 3.03 & 3.00 & 1075.0 & 209.9 & 199.3 & 5.3 \\
PE 10:0/10:0 & 522.320 & 1 & 3.85 & 3.81 & 1225.3 & 237.6 & 223.2 & -6.5 \\
PE 15:0/15:0 & 662.477 & 1 & 4.92 & 4.88 & 1400.8 & 270.2 & 253.3 & -6.7 \\
PE 17:0/17:0 & 718.539 & 1 & 5.39 & 5.35 & 1472.4 & 283.6 & 265.5 & -6.8 \\
PC 20:0/20:0 & 904.701 & 1 & & & & & & \\
PC 24:0/24:0 & 1016.826 & 1 & & & & & &
\end{tabular}

correction curve for dextran calibration in negative mode

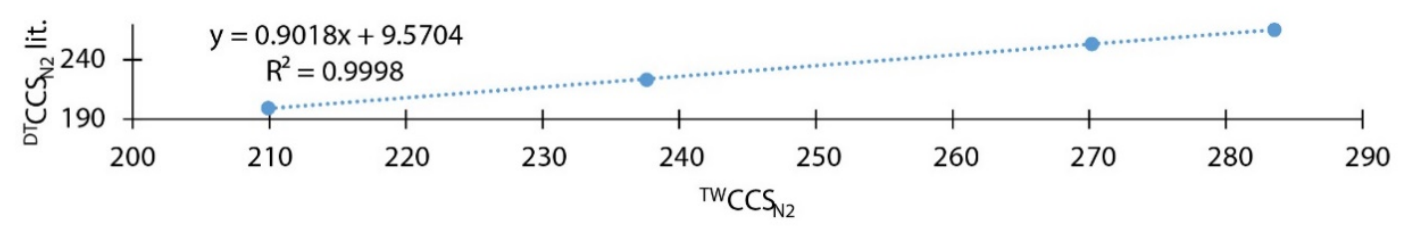

Equation A: lipid standards positive correction

$\begin{array}{lr}\mathrm{a} & 0.8107 \\ \mathrm{~b} & 32.5654 \\ & \\ \mathrm{r}^{2} & 0.9988\end{array}$

Equation B: lipid standards negative correction

$\begin{array}{ll}\text { a } & 0.9018 \\ b & 9.5704\end{array}$

$r^{2}$ 
Positive values Measured with polyalanine calibration

\begin{tabular}{|c|c|c|c|c|c|c|c|c|}
\hline Lipids & $\mathrm{m} / \mathrm{z}$ & $\mathrm{z}$ & $\mathrm{td}$ & $\mathrm{td}$ & $\mathrm{CCS}^{\prime}\left(\mathrm{N}_{2}\right)$ & ${ }^{{ }^{\mathrm{TW}} \mathrm{CCS}_{\mathrm{N} 2}}$ & ${ }^{\mathrm{DT}} \mathrm{CCS}_{\mathrm{N} 2}$ lit. & $\Omega \% \Delta$ \\
\hline PE 6:0/6:0 & 412.210 & 1 & 2.94 & 2.91 & 1036.1 & 202.3 & 202.1 & 2.3 \\
PE 10:0/10:0 & 524.335 & 1 & 4.06 & 4.02 & 1242.9 & 241.0 & 233.0 & -6.6 \\
PE 15:0/15:0 & 664.491 & 1 & 5.30 & 5.26 & 1444.0 & 278.5 & 265.0 & -9.1 \\
PE 17:0/17:0 & 720.554 & 1 & 5.76 & 5.72 & 1513.2 & 291.4 & 277.4 & -9.3 \\
PC 20:0/20:0 & 846.695 & 1 & 6.96 & 6.91 & 1683.1 & 323.2 & 306.4 & -10.3 \\
PC 24:0/24:0 & 958.820 & 1 & 7.98 & 7.93 & 1817.5 & 348.4 & 330.9 & -10.5
\end{tabular}

correction curve for polyalanine calibration in positive mode

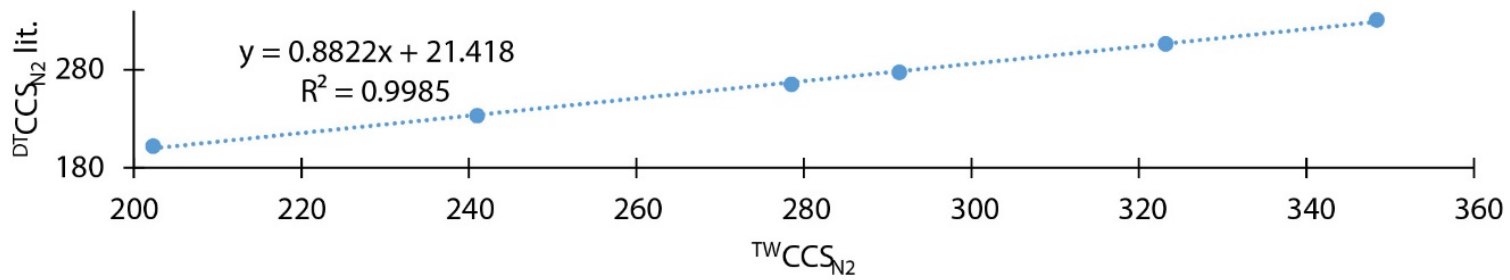

Negative values

Measured with polyalanine calibration

\begin{tabular}{|c|c|c|c|c|c|c|c|c|}
\hline Lipids & $\mathrm{m} / \mathrm{z}$ & z & $\mathrm{td}$ & $\mathrm{td}^{\prime}$ & $\operatorname{CCS}^{\prime}\left(\mathrm{N}_{2}\right)$ & ${ }^{\mathrm{TW}} \mathrm{CCS}_{\mathrm{N} 2}$ & ${ }^{\mathrm{DT}} \mathrm{CCS}_{\mathrm{N} 2}$ lit. & $\Omega \% \Delta$ \\
\hline PE 6:0/6:0 & 410.195 & 1 & 3.03 & 3.00 & 1033.2 & 201.8 & 199.3 & 5.3 \\
\hline PE 10:0/10:0 & 522.320 & 1 & 3.85 & 3.81 & 1185.5 & 229.9 & 223.2 & -6.5 \\
\hline PE 15:0/15:0 & 662.477 & 1 & 4.92 & 4.88 & 1364.7 & 263.2 & 253.3 & -6.7 \\
\hline PE 17:0/17:0 & 718.539 & 1 & 5.39 & 5.35 & 1438.1 & 276.9 & 265.5 & -6.8 \\
\hline PC 20:0/20:0 & 904.701 & 1 & & & & & & \\
\hline PC 24:0/24:0 & 1016.826 & 1 & & & & & & \\
\hline
\end{tabular}

correction curve for polyalanine calibration in negative mode

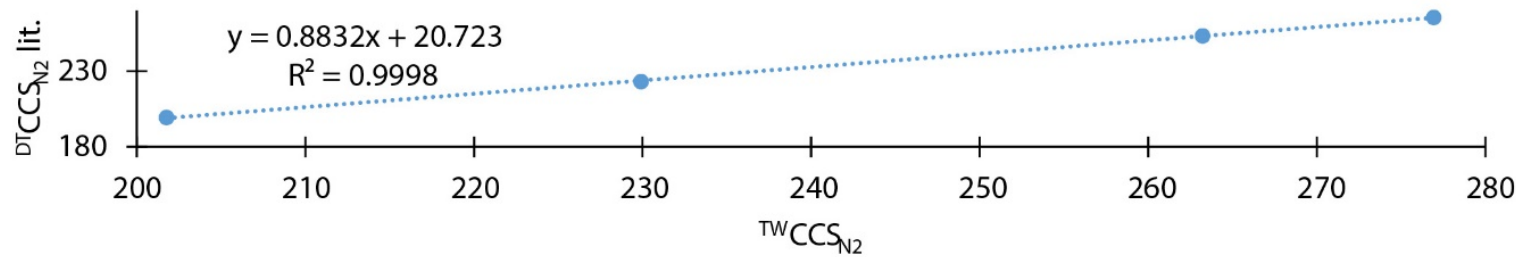

